NOVA Information Management School

Instituto Superior de Estatística e Gestão de Informação

Universidade Nova de Lisboa

\title{
UNDERSTANDING THE INDIVIDUAL-LEVEL DIGITAL DIVIDE: EVIDENCE OF AN AFRICAN COUNTRY
}

by

\author{
Glória Eduara Moura Gonçalves
}

Dissertation presented as partial requirement for obtaining the Master's degree in Information Management, with a specialization in Information Systems and Technologies Management

Co Advisors: Tiago André Gonçalves Félix de Oliveira, Ph.D.

Frederico Cruz Jesus, Ph.D.

November 2016 
In memory of Avô Rasga. 


\section{ACKNOWLEDGEMENTS}

I would like to thank my advisors, Professor Dr. Tiago Oliveira and Professor Dr. Frederico Cruz Jesus, for their patience and impeccable supervision.

Many thanks to my parents, brothers, sister, and all family members to whom I owe profound gratitude for the support and participation in my intellectual and personal growth.

To my masters colleagues who collaborated in classes and group works.

I would like to express my particular gratitude to all who contributed to the data collection. A special thanks to the Faculty of Sciences' community at Agostinho Neto University. 


\begin{abstract}
Digital divide, the differential in access and use of information and communication technologies (ICT) represents an obstacle to the information society, and general wellbeing. This study combines the extended unified theory of acceptance, and use of technology (UTAUT2) (Venkatesh, Thong, \& Xu, 2012), Schwartz's basic human values theory (Schwartz, 1992) and ICT skills to: (1) understand which factors influence ICT acceptance among individuals; (2) explore the role of basic values on ICT acceptance; and, (3) examine how these factors explain the digital divide. The research model was tested in the context of a sub-Saharan country. Empirical results suggest that ICT use is mainly influenced by behavioral intention, habit, and ICT skills. Hedonism, achievement, benevolence, and universalism were the most significant values.
\end{abstract}

\title{
KEYWORDS
}

Digital divide; technology adoption; ICT; basic values; ICT skills. 


\section{RESUMO}

A divisão digital, a diferença de acesso e uso das tecnologias da informação e da comunicação (TIC), constitui um obstáculo à sociedade da informação e ao bem-estar geral. Este estudo combina a teoria unificada de aceitação e uso de tecnologia (UTAUT2 - extended unified theory of acceptance, and use of technology) (Venkatesh, Thong, \& Xu, 2012), a teoria de valores humanos básicos de Schwartz (Schwartz, 1992) e as competências em TIC para: (1) compreender quais fatores influenciam a aceitação das TIC entre indivíduos; (2) explorar o papel dos valores básicos na aceitação das TIC; E, (3) examinar como esses fatores explicam a divisão digital. O modelo de pesquisa foi testado no contexto de um país subsaariano. Resultados empíricos sugerem que o uso das TIC é influenciado principalmente pela intenção comportamental, hábito e as competências em TIC. Hedonismo, realização, benevolência e universalismo foram os valores mais significativos.

\section{PALAVRAS-CHAVE}

Divisão digital; adoção de tecnologia; TIC; valores básicos; competências em TIC. 


\section{SUBMISSION}

\section{SUBMISSION RESULTING FROM THIS DISSERTATION}

\section{PAPER}

Gonçalves, G., Oliveira, T, Cruz-Jesus, F. UNDERSTANDING THE INDIVIUAL-LEVEL DIGITAL DIVIDE: EVIDENCE OF AN AFRICAN COUNTRY. (Submission to a Journal) 


\section{INDEX}

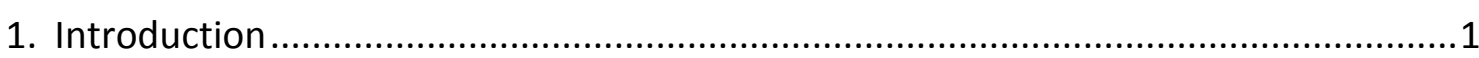

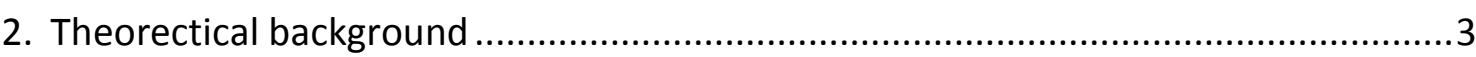

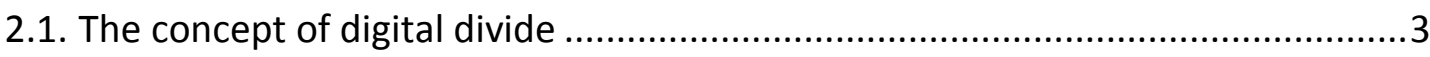

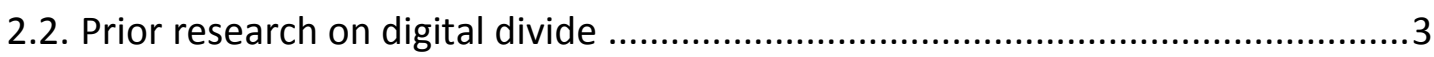

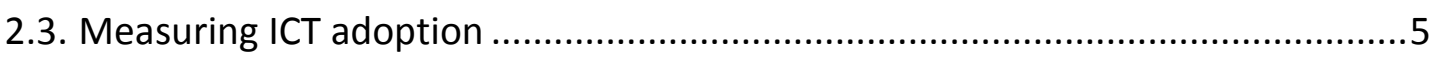

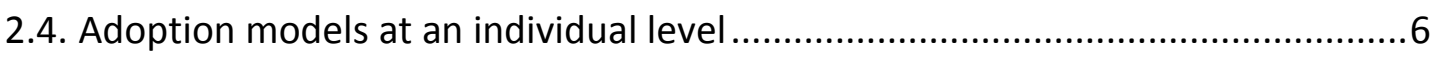

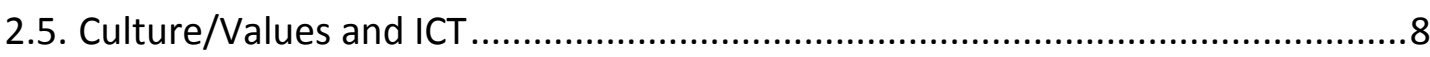

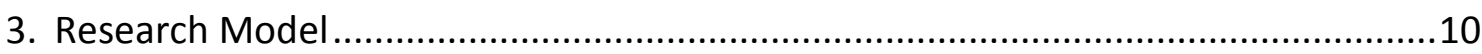

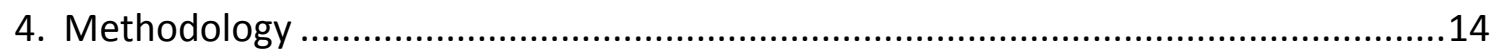

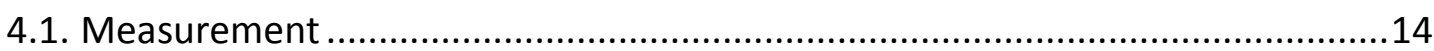

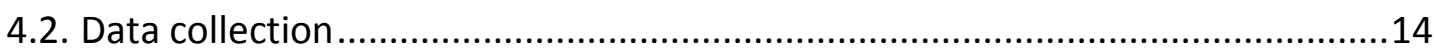

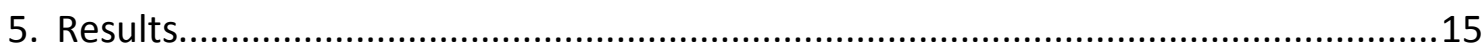

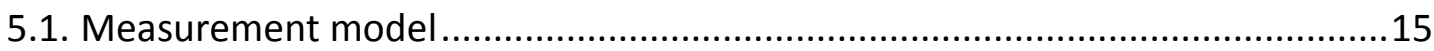

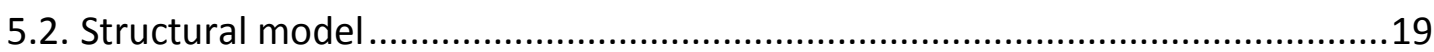

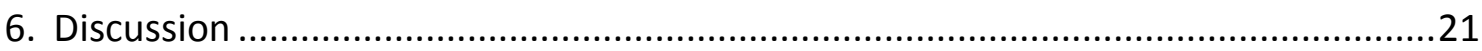

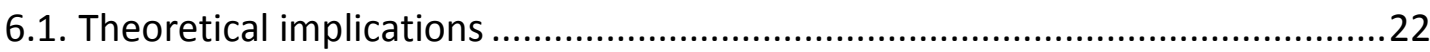

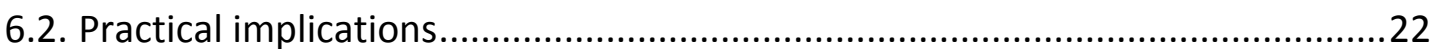

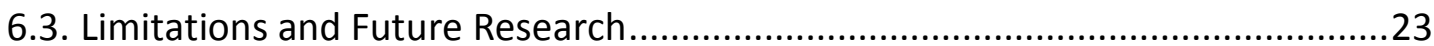

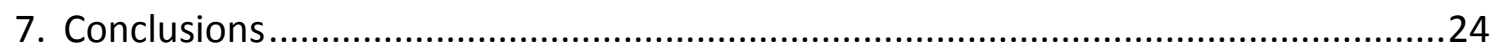

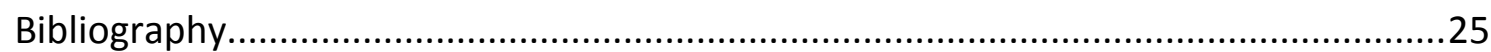

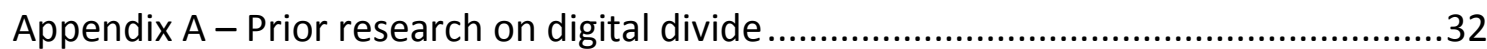

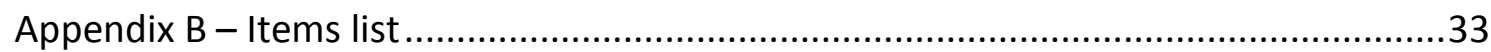

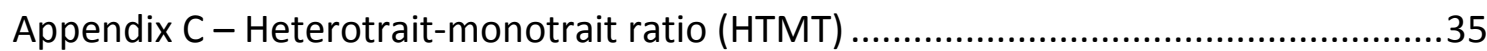




\section{LIST OF FIGURES}

Figure 2.1 - Schwartz's theoretical model (Schwartz, 2012) ............................................. 9

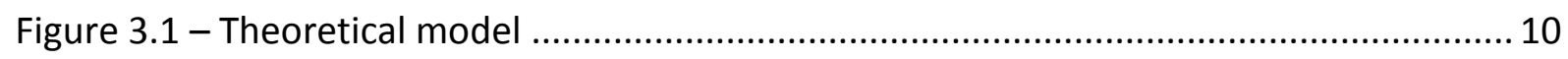




\section{LIST OF TABLES}

Table 2.1 - ICT-related technologies previously used to study the digital divide 6

Table 2.2 - Summary of studies about adoption models at the individual level to explain digital divide 8

Table 4.1 - Sample characteristics 14

Table 5.1 - Loadings and Cross-Loadings..... 16

Table 5.2 - Descriptive statistics, correlations and AVEs... 18

Table 5.3 - Structural model results 19 


\section{LIST OF ABBREVIATIONS AND ACRONYMS}

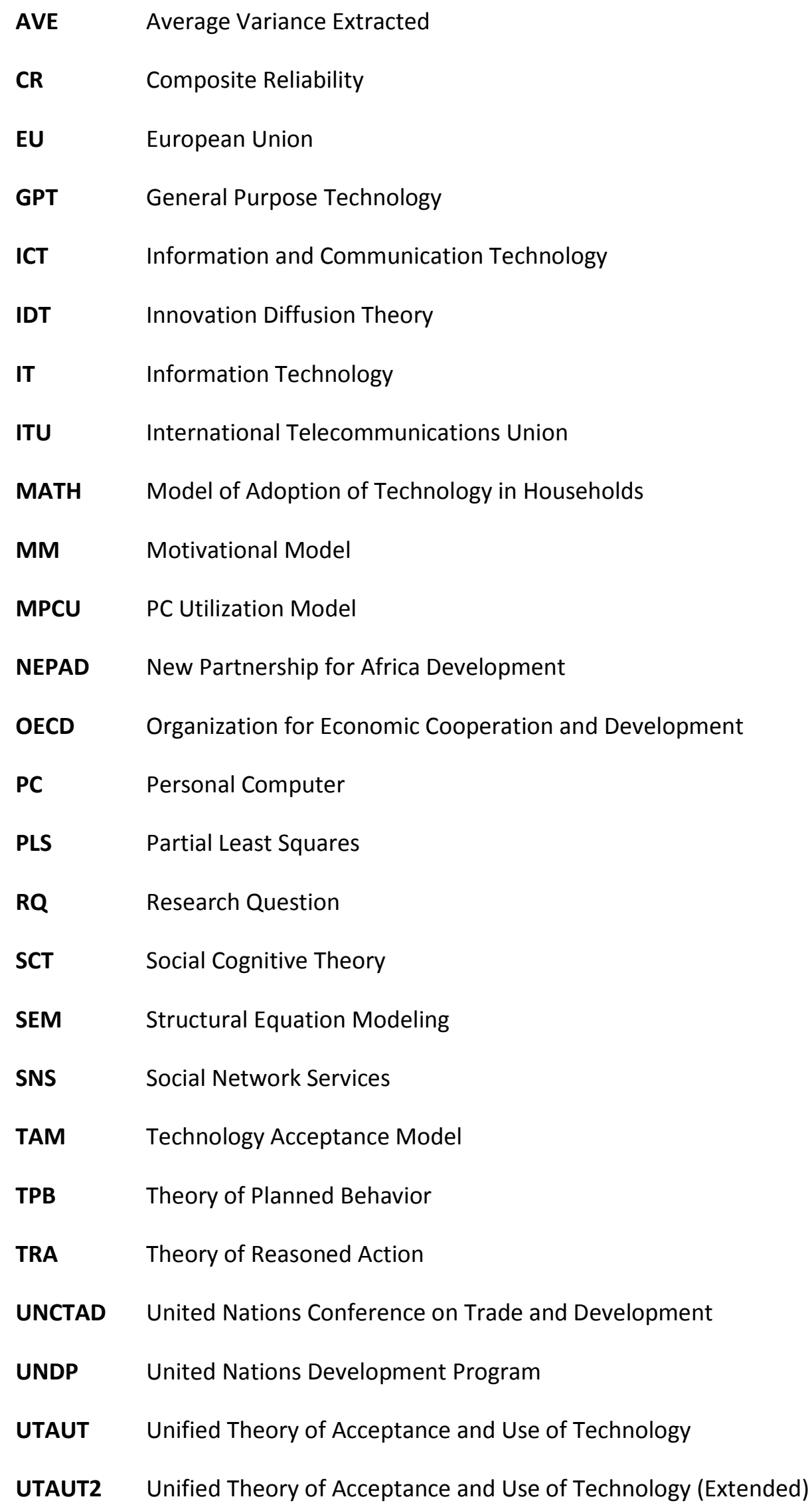




\section{INTRODUCTION}

Information and communication technologies (ICT) have become an important part of contemporary society. These technologies can be used for a large range of everyday activities and has affected business, governments and individuals by including new, or modified means of communication and interaction (OECD, 2011). ICT represent an opportunity for both social and economic growth (Doong \& Ho, 2012; Xiaoqun Zhang, 2017), but at the same time, inequalities in access and use of ICT can prevent certain groups from exploring these opportunities, to fully participate in society and, thus, create a new group of disadvantaged people. This inequality of access and use is known as the digital divide. In general, digital divide refers to the gap between those who do have access and use ICT and those who do not (Dewan \& Riggins, 2005).

The past years have been characterized by unprecedented growth and spread of ICT, however, the digital divide remains, and even seems to be ever widening in some segments (ITU, 2014b). The reasons behind this fact have to do, firstly, because ICT diffusion does not take place uniformly across countries, regions, nor individuals (OECD, 2004; US Department of Commerce, 2002). In second place, ICT include a variety of technologies, not only computers and Internet (Selwyn \& Facer, 2007). Hence, these technologies include advanced services and the usage of different types of media which demands the presence of digital skills alongside basic reading and writing abilities (OECD, 2011; van Dijk, 2006). All of these factors are drawing pronounced differences between individuals who have access to new forms of information technology and those who do not. Within this context, understanding the causes behind individual ICT acceptance became a matter of importance which has drawn the attention of both researchers, international organizations and policy-makers. For instance, at the World Summit on the Information Society (2005), it was recognized that ICT is a core basis for an inclusive information society and the importance of measuring ICT development was emphasized. The European Commission, via the Digital Agenda for Europe, defined the role that ICT should play to turn the European Union into "a smart, sustainable and inclusive economy" (European Commission, 2010b, p. 3). The digital divide represents an obstacle that needs to be overcome in order to build a society where everyone can create, access, utilize and share information and knowledge (WSIS, 2005).

Despite the contributions in this research area, there is a lack of studies addressing the digital divide phenomena from the theoretical perspective of technology adoption models (Hsieh, Rai, \& Keil, 2008), which is a central research area in information systems literature (Bhattacherjee \& Sanford, 2006). To the best of the authors' knowledge, few studies have used this approach (e.g., Hsieh et al., 2008; Niehaves \& Plattfaut, 2014). Nevertheless, these studies usually focus on a specific technology - usually the Internet - and, therefore, do not include all of the ICT extent. Drawing from digital divide literature, technology adoption and personal values, this study aims to understand the drivers that explain the digital divide/ICT acceptance at an individual level in the context of a sub-Saharan country following the suggestion of Venkatesh, Thong and Xu (2012) to test the extended unified theory of acceptance and use of technology (UTAUT2) in other countries and technologies. In the specific context of the digital divide, we find this recommendation of special relevance, as most of the individual-level information technology (IT) adoption studies are held in developed countries. Moreover, according to the United Nations Development Program (UNDP) (2015), Africa in particular sub-Saharan Africa, is the least developed region of the world in terms of income, life expectancy and 
school attainment. Thus, understanding individual-level digital divide in developing countries is a critical issue to advance the living conditions and welfare of millions of individuals that, currently, most need it. Hence, we intend to answer the following research questions (RQs):

RQ1 - What are the main drivers of individual-level ICT acceptance?

RQ2 - To what extent does UTAUT2 explain the individual level digital divide?

RQ3 - Does one's personal values affect ICT acceptance? And how so?

RQ4 - What measures can be developed by policy-makers of developing countries to effectively engender ICT acceptance by its individuals?

In answering these questions, the paper is organized as follows: section two has the theoretical background; section three the conceptual model developed in the context of this study; section four includes the methodology, whereas the fifth section has the results. In the sixth section, both theoretical and practical implications are addressed, as also the study limitations, and future research. The conclusions of this paper are in the last section. 


\section{THEORECTICAL BACKGROUND}

\subsection{THE CONCEPT OF DIGITAL DIVIDE}

Since the publication of the "Falling Through the Net" series reports (NTIA, 1995, 1998, 1999, 2000), the digital divide gained attention and became an important topic among researchers and governments around the world (Hargittai, 2006). Although the origin of the term is still uncertain (Gunkel, 2003), it is frequently associated to the former Assistant Secretary for Communication and Information of the US Department of Commerce's, Larry Irving Junior.

In the first years, the concept digital divide was commonly understood as the gap between those who have access to ICT and those who do not (Dewan \& Riggins, 2005; van Dijk, 2006), where access referred to the possession of a personal computer (PC) and the means to connect the Internet (Dimaggio, Hargittai, Celeste, \& Shafer, 2001). Consequently, it was implicit that the digital divide could be solved by simply providing access to ICT (Hsieh et al., 2008). Neglecting the fact that access is just the first step and does not guarantee continued use (Brandtzæg, Heim, \& Karahasanović, 2011; Karahanna, Straub, \& Chervanny, 1999). Later on, however, as researchers increasingly started to move beyond differences in access, the initial definition was found narrow and the digital divide concept was expanded (van Dijk, 2006). Presently the understanding of this subject includes not only the disparities regarding access, but also in the different ways of ICT use (Brandtzæg, Heim, \& Karahasanović, 2011) - named first and second digital divides, respectively (Dewan \& Riggins, 2005). Although there is no ultimate digital divide definition, this study considers the one (perhaps) most widely used, provided by the Organization for Economic Cooperation and Development (OECD) which refers to "the gap between individuals, households, businesses and geographic areas at different socio-economic levels with regard to both their opportunities to access information and communication technologies and their use of the Internet for a wide variety of activities" (OECD, 2001, p. 5).

\subsection{PRIOR RESEARCH ON DIGITAL DIVIDE}

One stream of digital divide research focus on inequalities across countries, that is, global-level digital divide. To name a few, Cuervo and Menéndez (2006) and Cruz-Jesus et al. (2012) studied the digital divide in the European Union (EU) countries, concluding that digital imbalances reflect the social and economic disparities between Member States. Dewan, Ganley and Kraemer (2010), conducted a cross-country study on the diffusion of PC and the Internet, concluding that the diffusion of these technologies has been slower in developing countries. Brandtzæg et al. (2011) focused on the different patterns of Internet usage across Europe, concluding that most of the citizens were either non- or sporadic users.

Besides the global digital divide, there is also a divide between regions and groups of individuals within countries, that is, the domestic digital divide (Dewan \& Riggins, 2005). In this stream of research, the first studies primarily focused on a simplistic and binary perspective of "have" versus "have not" access to ICT. During the 90s a series of surveys in the United States highlighted these inequalities particularly on computer and Internet adoption (Selwyn, 2006). Statistical data regarding PC and Internet penetration were collected and analyzed under socio-economic and demographic points of view, taking into consideration factors such as: gender, age, ethnicity, income and 
education (see, e.g., Hoffman \& Novak, 1998; NTIA, 1995, 1998, 1999; Payton, 2003). A great part of these studies concluded that the inequality of access was mostly driven by the differences in income and education levels. Also, these studies pointed out that individuals belonging to minority ethnical groups were less likely to have access to ICT.

Afterward, researchers began to focus on use behavior once access had been granted (Attewell, 2001; NTIA, 2000; Payton, 2003). It was found that people used technology mostly for educational purposes and as a communication tool (NTIA, 1999). Similarly, to what happened with access, education and income ended up being the main predictors of ICT use. Bonfandelli (2002) asserted that people with higher education use the Internet in an instrumental way, while people with lower education use Internet mostly for entertainment purposes. Regarding level of income, Eamon (2004) concluded that poor youth are likely to use computers for productive purposes as often as non-poor youth. Researchers also demonstrated that technology adoption models may be able to provide better understanding of digital divide especially, when analyzed under a socio-demographic perspective, taking into consideration already familiar factors such as: gender, age, ethnicity, income and education. For instance, Hsieh et al. (2008) decomposed the theory of planned behavior (TPB) to understand user acceptance of ICT between socio-economically advantaged and disadvantaged. These authors showed that different factors affect continued use intention for both groups, where attitude and hedonic outcomes were more influential for disadvantaged people. Niehaves and Plattfaut (2014) studied age-related digital divide in the adoption of the Internet by the elderly by comparing two theories, the model of adoption of technology in households (MATH), and the unified theory of acceptance and use of technology (UTAUT). Both UTAUT, and MATH were able to explain Internet adoption. Nevertheless, MATH had a superior explanatory power, while UTAUT had a greater feasibility. More recently, the digital divide debate has been focused in another dimension, the necessary skills in using ICT. A study by van Dijk (2006) showed how the digital divide is shaped by four types of access: motivational, physical, skills, and usage. Whereas the first three are necessary conditions for actual technology use. The skills access includes the possession of three types of digital skills: operational, information, and strategic. According to the author, at least in developed countries, the access divide is closing whereas the skills divide tends to increase. In a study regarding the divide among Web content creation, Correa (2010) hypothesized that online skills are related to greater levels of content creation, however, skills are found not to be significant when perceived competence, meaning feeling able to perform a task regardless of the skills, was considered. The results of a study by Ferro, Helbig and Gil-Garcia (2011), showed that IT literacy influences Internet use more than income, age, and having a home PC. For these authors, IT literacy can be seen, at the same time, as a factor of the digital divide and a division itself.

This line of research showed that the digital divide is a broader and more complex subject than mere technology access. It is a multidimensional phenomenon that requires deep analysis (Cuervo \& Menéndez, 2006) of the social, cultural and psychological causes behind it (van Dijk, 2006). There is not one digital divide (Gunkel, 2003), it exists in many forms between: individuals, countries, regions (Dragulanescu, 2002) and may even exist between different organizations as Dewan and Riggins (2005) asserted. In this study, the digital divide is analyzed from a technology adoption perspective where the behavior of interest is the use of ICT once access had been granted (i.e. second order digital divide). For a comprehensive literature review please see Appendix A. 


\subsection{MEASURING ICT ADOPTION}

Considering the fact that digital divide is characterized by the differences in ICT adoption, by being able to understand them, we will be able to shed some light on the subject. Weber and Kauffman (2011) defined ICT as "technologies that support data and information processing, storage and analysis, as well as data and information transmissions and communication via the Internet and other means" (p. 684). Accordingly, some authors (e.g., Cruz-Jesus et al., 2012; Cuervo \& Menéndez, 2006; Doong \& Ho, 2012) conceptualized ICT as a general purpose technology (GPT), meaning innovations with the potential to impact a wide range of sectors in a society (Guerrieri \& Padoan, 2007). These technologies are characterized by their pervasiveness of use and technological dynamism. According to Selwyn and Facer (2007), there is a broad and a diverse range of technologies that can be considered as ICT, including goods and services (UNCTAD, 2011). From these perspectives, ICT can be seen as a diverse set of technologies that enable information processing and communication by electronic means which can be used for a wide range of everyday activities and has a constantly changing landscape.

Considering the complex and dynamic nature of ICT, measuring its adoption is a challenging task (Cruz-Jesus et al., 2012). The pervasiveness of ICT in almost every aspect of our society (e.g., social, economic, political, cultural) (OECD, 2011), as well as the wide variety of frameworks (Schlichter \& Danylchenko, 2014) creates serious difficulties. Some of the existing conceptual measurement frameworks were developed by international organizations such as the International Telecommunications Union (ITU), the OECD, the United Nations Conference on Trade and Development (UNCTAD) and the World Bank (ITU, 2014a) with the aim of explaining ICT adoption, using several indicators regarding ICT infrastructure, access and use, to calculate composite indices which indicate the level of ICT adoption of a country. Another approach found in the literature is the use of multivariate methods to assess the complexity of ICT development (Cruz-Jesus, Vicente, Bacao, \& Oliveira, 2016; Cuervo \& Menéndez, 2006). At an individual level, studies concerning ICT acceptance usually focus on a single technology or a small group of technologies. For instance, Liao, Chen and Yen (2007) addressed the continued use of online services; Andrade and Doolin (2016) conducted a study to understand how Internet and social media influence social inclusion of refugees in New Zealand. However, some authors (e.g., Billon, Marco, \& Lera-Lopez, 2009; Cruz-Jesus et al., 2012) argued that a single technology is not enough to study ICT adoption. Thus, to achieve a better understanding ICT is conceptualized considering several technologies. In order to select the ICTrelated technologies an analysis of previous studies was conducted (please see Table 2.1). Even though some of these variables were used in global level analysis, they derived from aggregated data of individuals. 


\begin{tabular}{|c|c|c|c|c|c|c|c|c|c|}
\hline \multirow[t]{2}{*}{ Source } & \multicolumn{9}{|c|}{ ICT-related technologies / Variables } \\
\hline & Int & Mob & email & eBank & eCom & eLearn & eHealth & eGov & SNS \\
\hline $\begin{array}{c}\text { (Çilan, Bolat, \& Coşkun, } \\
\text { 2009) }\end{array}$ & $\mathrm{x}$ & & & & $x$ & $\mathrm{x}$ & & $\mathrm{x}$ & \\
\hline $\begin{array}{l}\text { (European Commission, } \\
\text { 2010a) }\end{array}$ & & & & $\mathrm{x}$ & $x$ & $x$ & $x$ & $x$ & \\
\hline$(\mathrm{OECD}, 2011)$ & $\mathrm{X}$ & $x$ & $\mathrm{X}$ & $x$ & $x$ & & & $\mathrm{X}$ & \\
\hline (Schradie, 2011) & & & & & & & & & $\mathrm{x}$ \\
\hline (Cruz-Jesus et al., 2012) & $x$ & $x$ & $x$ & $x$ & & $\mathrm{x}$ & $x$ & $\mathrm{x}$ & \\
\hline (Lee, Park, \& Hwang, 2015) & $x$ & & & & & & & & \\
\hline $\begin{array}{l}\text { (Schlichter \& Danylchenko, } \\
\text { 2014) }\end{array}$ & $x$ & $x$ & $x$ & $x$ & $x$ & $x$ & $x$ & $\mathrm{x}$ & \\
\hline (ITU, 2014a) & $x$ & & $x$ & $\mathrm{x}$ & $\mathrm{X}$ & $x$ & $x$ & $\mathrm{X}$ & $x$ \\
\hline $\begin{array}{c}\text { (Várallyai, Herdon, \& Botos, } \\
\text { 2015) }\end{array}$ & $x$ & $x$ & & $\mathrm{x}$ & $x$ & $x$ & & $x$ & \\
\hline (Cruz-Jesus et al., 2016) & $x$ & $x$ & & $x$ & $x$ & $x$ & $x$ & $x$ & \\
\hline
\end{tabular}

Table 2.1 - ICT-related technologies previously used to study the digital divide

The Internet, a key aspect for societal activity (European Commission, 2010a), is often used in literature to measure ICT adoption (Cruz-Jesus et al., 2012; ITU, 2014a; OECD, 2011). According to Doong and Ho (2012), the number of individuals using mobile devices to access the Internet has grown. Lee et al. (2015) even stated that smartphones have emerged as a new dimension of the digital divide. E-mail has been a common solution for communication (Andrade \& Doolin, 2016). For these reasons, regular Internet use (Int), the use of mobile devices to access the Internet (Mob), and sending/receiving e-mails (email) are considered in our study. Consistent with the literature (CruzJesus et al., 2012; ITU, 2014a; OECD, 2011), e-banking (eBank), e-commerce (eCom), e-learning (eLearn), e-health (eHealth), and e-government (eGov) are also considered, since they represent some of the most advanced electronic services (European Commission, 2010a). According to ITU (2014b) more and more people are participating in the information society by using social media in both developed and developing countries. Therefore, the use of social network services (SNS) is also considered as part of general-ICT adoption.

Regarding the selected technologies, although we acknowledge that our set is not exhaustive in terms of representing all multiple facets of ICT, we believe that it successfully reflects the pervasiveness of ICT in different sectors of society.

\subsection{ADOPTION MODELS AT AN INDIVIDUAL LEVEL}

Originally from a psychology, sociology, and information systems point of view, technology adoption has been extensively studied and several theories and models have been proposed (Venkatesh, Morris, Davis, \& Davis, 2003) in order to explain attitudes and behavior towards technology (Agarwal \& Karahanna, 2000). According to Qingfei, Shaobo and Gang (2008), the most influential among several models at an individual level that have been developed, include the theory of reasoned action (TRA) (Fishbein \& Ajzen, 1975), TPB (Ajzen, 1991), the technology acceptance model (TAM) (Davis, 1989), and most recently UTAUT (Venkatesh et al., 2003). All these theories are based on the concept that individual reactions lead to intention to use a particular technology which in turn, lead to actual use (Venkatesh et al., 2003). 
Venkatesh et al. (2003) developed the UTAUT based on eight prominent previously established theories: TRA, TAM, motivational model (MM) (Davis, Bagozzi, \& Warshaw, 1992), TPB, PC utilization model (MPCU) (Thompson, Higgins, \& Howell, 1991), innovation diffusion theory (IDT) (Rogers, 1995), social cognitive theory (SCT) (Bandura, 1986), and combined TAM and TPB (C-TAM-TPB) (Taylor \& Todd, 1995). UTAUT proposes four constructs, three of which are main determinants of intention to use, namely: performance expectancy, effort expectancy, and social influence; while the fourth, facilitating conditions jointly with behavioral intention are theorized to direct influence usage behavior (Venkatesh et al., 2012). In addition, four moderating variables which affect the relationship between the constructs and the dependent variables are considered, namely: age, gender, experience, and voluntariness of use. Since its publication, UTAUT has been applied in a wide variety of studies to explore technology adoption (Venkatesh, Thong, \& Xu, 2016). It was applied in different technologies such as mobile commerce (Qingfei et al., 2008), tablet (Magsamen-Conrad, Upadhyaya, Joa, \& Dowd, 2015), Internet banking (Martins, Oliveira, \& Popovic, 2014), mobile banking (Zhou, Lu, \& Wang, 2010), and e-government (Kurfalı, Arifoğlu, Tokdemir, \& Paçin, 2017) with different control factors. For instance, Niehaves and Plattfaut (2014) also used this same model to explain age-related digital divide focusing on Internet adoption by the elderly. Although UTAUT was considered one of the most important theories of IT adoption (Qingfei et al., 2008), it has some limitations (Baptista \& Oliveira, 2015). In 2012 Venkatesh et.al. (2012) proposed UTATU2, which extends UTAUT to consumer acceptance, and use context. The UTAUT2 model incorporates three new constructs: habits, hedonic motivation, and price value. According to UTAUT2 performance expectancy, effort expectancy, social influence, hedonic motivation, and price value are hypothesized to have direct relationship with the dependent variable behavioral intention, while facilitating conditions, and habit have direct influence in both behavioral intention, and use behavior. The model also abandons voluntariness as a moderating variable, keeping only age, gender, and experience from the previous UTAUT.

Table 2.2 summarizes some of the research based on the theories previously mentioned that address digital divide, only three studies emerge (Chen, Lin, \& Lai, 2010; Hsieh et al., 2008; Niehaves \& Plattfaut, 2014) and none have analysed more than one technolgy. Hence, our study intends to help bridge the gap in the literature.

\begin{tabular}{|c|c|c|c|c|c|}
\hline Study objectives & $\begin{array}{l}\text { ICT under } \\
\text { study }\end{array}$ & Theories & Variables & Findings & Authors \\
\hline $\begin{array}{l}\text { Investigate } \\
\text { differences in the } \\
\text { factors affecting } \\
\text { continued use } \\
\text { intention of } \\
\text { Internet TV } \\
\text { among socio- } \\
\text { economically } \\
\text { advantaged and } \\
\text { disadvantaged } \\
\text { groups }\end{array}$ & Internet TV & TPB & $\begin{array}{l}\text { Internet TV continued use } \\
\text { intention, attitude, hedonic } \\
\text { outcomes, utilitarian } \\
\text { outcomes, subjective norms, } \\
\text { family relatives friends and } \\
\text { peers' influence, } \\
\text { governmental influence, } \\
\text { perceived behavioral control, } \\
\text { self-efficacy, perceived ease } \\
\text { of use, availability, personal } \\
\text { network exposure, Internet } \\
\text { PC ownership }\end{array}$ & $\begin{array}{l}\text { Attitude has a stronger } \\
\text { influence on Internet TV } \\
\text { continuance use intention. } \\
\text { Social network affects } \\
\text { post-implementation and } \\
\text { acceptance of Internet TV }\end{array}$ & $\begin{array}{c}\text { (Hsieh et al., } \\
\text { 2008) }\end{array}$ \\
\hline $\begin{array}{l}\text { Investigate } \\
\text { China's rural } \\
\text { digital divide }\end{array}$ & Internet & TPB & $\begin{array}{l}\text { Utilitarian outcomes, hedonic } \\
\text { outcomes, perceived risk, } \\
\text { social network influence, } \\
\text { government influence, self- } \\
\text { efficacy, availability, attitude, } \\
\text { subjective norms, perceived } \\
\text { behavioral control, continued }\end{array}$ & $\begin{array}{l}\text { Hedonic outcomes are } \\
\text { important to shape } \\
\text { attitudes toward Internet } \\
\text { continued use intention. } \\
\text { Perceived risk exerted } \\
\text { significant impact for rural } \\
\text { residents. }\end{array}$ & $\begin{array}{c}\text { (Chen et al., } \\
\text { 2010) }\end{array}$ \\
\hline
\end{tabular}




\begin{tabular}{|c|c|c|c|c|c|}
\hline & & & use intention & & \\
\hline $\begin{array}{l}\text { Understand the } \\
\text { age-related digital } \\
\text { divide }\end{array}$ & Internet & $\begin{array}{c}\text { UTAUT and } \\
\text { MATH }\end{array}$ & $\begin{array}{l}\text { Behavioral intention to adopt } \\
\text { Internet, performance } \\
\text { expectancy, effort } \\
\text { expectancy, social influence, } \\
\text { education, gender, income, } \\
\text { age }\end{array}$ & $\begin{array}{l}\text { The added socio- } \\
\text { demographic variables } \\
\text { increase the coefficient of } \\
\text { determination of the } \\
\text { models. Education has a } \\
\text { positive effect on Internet } \\
\text { adoption }\end{array}$ & $\begin{array}{c}\text { (Niehaves \& } \\
\text { Plattfaut, } \\
\text { 2014) }\end{array}$ \\
\hline
\end{tabular}

Table 2.2 - Summary of studies about adoption models at the individual level to explain digital divide

\subsection{Culture/VALUeS AND ICT}

Some studies (e.g., Baptista \& Oliveira, 2015; Srite \& Karahanna, 2006; Udo, Bagchi, \& Kirs, 2012) have pointed out the significant role that cultural factors play in technology adoption. According to Zhang and Maruping (2008), the most popular conceptualization of culture among researchers has been the work developed by Hofstede (1980) which classifies countries along four cultural dimensions: individualism/collectivism, power distance, uncertainty avoidance, and masculinity/femininity. Srite and Karahanna (2006) examined the espoused cultural values on technology acceptance. They posit that national culture impacts individuals' cultural values, and subsequently affects technology acceptance. Similarly, Udo et al. (2012) studied the role of espoused cultural values on e-services acceptance. Baptista and Oliveira (2015) used cultural factors to explain mobile banking acceptance in Mozambique. These authors concluded that cultural moderators were an important driver of behavior intention over use behavior. However, according to Smith (2002) culture is made up by individuals, and comprises a set of shared values. Bagchi et al. (2015) asserted that while cultural factors are variables in which groups differ, values are variables in which individuals differ. Values serve as the basic criteria in which individuals select and justify actions and events (Schwartz, 1992). Furthermore, values are beliefs that refer to desirable goals that motivate action (Schwartz, 2012).

Schwartz developed a theory at the individual level concerning basic values that people, in all cultures, presumably recognize (Schwartz, 2012). The theory of basic human values (Schwartz, 1992) identifies 10 motivationally distinct types of values namely: self-direction, stimulation, hedonism, achievement, power, security, conformity, tradition, benevolence, and universalism. These values are grouped into four high-level values: self-enhancement, openness to change, self-transcendence, and conservation (please see Figure 2.1). Where openness to change refers to readiness, and openness to new experiences; conservation emphasize order, preservation and avoidance to change; selfenhancement relates to success and dominance; and self-transcendence concerns the welfare of the others. In addition, the theory specifies the dynamic relations among each value in a circular structure. Adjacent values are compatible and opposite values conflict with each other forming a motivational continuum. For instance, openness to change values contrasts with conservation, selfenhancement values contrasts with self-transcendence values. The tradeoff among competing values serves as guiding principles in life (Schwartz, 1992). In 2012, the theory of basic human values was refined, as Schwartz et al. (2012) proposed a larger and more conceptually detailed set of values, where some values were partitioned into two or more subtypes. 


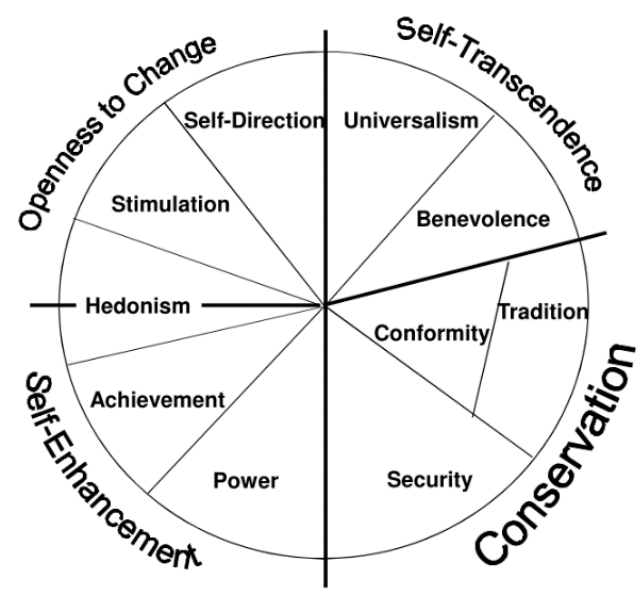

Figure 2.1 - Schwartz's theoretical model (Schwartz, 2012)

The values theory has for example, been used to study: political preferences, environmental attitudes, and human rights (Davidov, Schmidt, \& Schwartz, 2008). Nevertheless, few studies applied this theory in technology adoption. For instance, in a study about the most influential experiences in successful and unsuccessful technology adoption Partala and Saari (2015) found that values (except security) are related to successful technology adoption. Bagchi et al. (2015) developed a model using the Schwartz values framework to study Internet use. They concluded that personal values affect Internet use, with the exception of the power value, which ended up being not influential. 


\section{RESEARCH MODEL}

An integrated model (please see Figure 3.1), combining constructs from UTAUT2, the Schwartz basic human values theory, and ICT skills, serves as theoretical lenses for understanding the individual level ICT acceptance/digital divide behavioral intention and behavior. According to Baptista and Oliveira (2015), UTAUT2 provides a better explanation of variance for both behavioral intention and technology use than its predecessor, which was considered the most complete model to predict technology adoption (Martins et al., 2014). Thus, the UTAUT2 model is used in this study. Considering that ICT is characterized by the perceived social impact, due to the facts that have changed individuals' lifestyles (European Commission, 2010a), and the digital divide is considered in the literature as a social phenomenon (Dewan \& Riggins, 2005; OECD, 2011). In order to provide a deeper understanding of ICT's individual acceptance, we believe that the values concept which is an important construct in social sciences and all the areas concerned with human behavior (Schwartz, 1992), provides new insights into technology acceptance, since values has been considered in psychology literature as one of factors that influence behavior (Bardi \& Schwartz, 2003). Therefore, Schwartz's basic values are also used in the model.

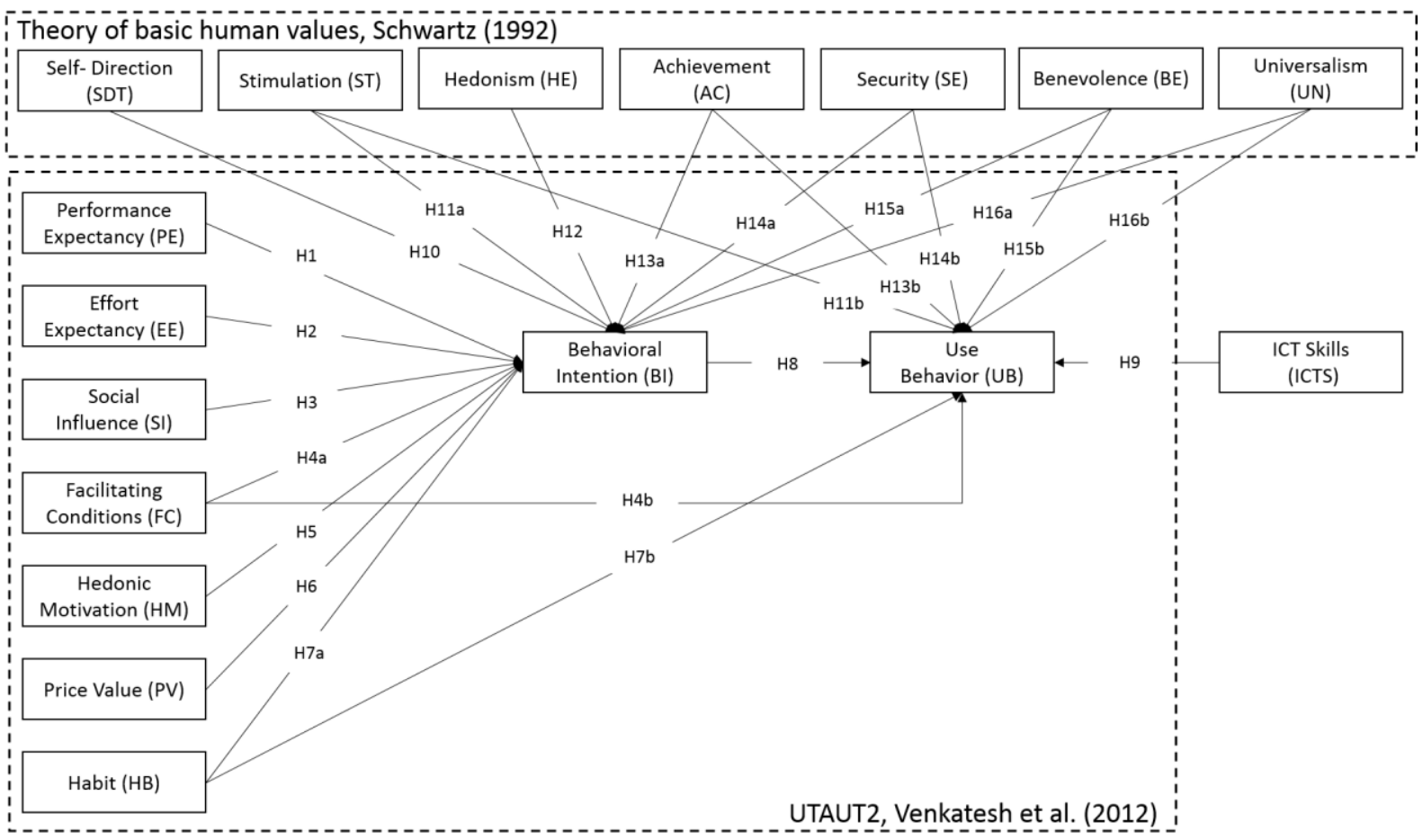

Figure 3.1 - Theoretical model

Performance expectancy is defined as the degree to which an individual believes that a particular technology will enhance personal performance (Venkatesh et al., 2003). It reflects the perception of utility gained from using ICT. For instance, performance expectancy was found to have great influence on Internet adoption (Niehaves \& Plattfaut, 2014) and mobile banking (Baptista \& Oliveira, 2015), specific applications of ICT and, thus, associated with the concept of digital divide. Therefore, we hypothesize:

H1. The influence of performance expectancy (PE) on behavioral intention (BI) will be positive. 
Effort expectancy is the degree of ease associated to the use of technology (Venkatesh et al., 2003). According to Agarwal and Karahanna (2000), individuals are more likely to interact with technology if they perceive that they will expend little effort. Moreover, in research about the digital divide, it is often argued that the easier the use of ICT is, the likelier one is to use them (Cruz-Jesus et al., 2016; Hsieh et al., 2008), which is in the realm of considering education as an important aspect of digital inequalities. It is natural for one to hypothesize that the less complex ICT seem to one person, the more prone it is that same individual to use them. Therefore, we hypothesize:

H2. The influence of effort expectancy (EE) on behavioral intention (BI) will be positive.

Social influence represents the degree to which an individual perceives it to be important that others (e.g., family and friends) believe he or she should use a particular technology (Venkatesh et al., 2003). Earlier studies found for instance, that social influence affects household PC adoption (Venkatesh \& Brown, 2001) and Internet (Niehaves \& Plattfaut, 2014) which are some specific examples of ICT. Moreover, in developing countries, the importance of others in individual decisions is high (Venkatesh \& Sykes, 2013). Therefore, we hypothesize:

H3. The influence of social influence (SI) on behavioral intention (BI) will be positive.

Facilitating conditions defines the degree to which an individual believes that the resources and support to use a particular technology are available (Venkatesh et al., 2012). Regarding ICT, facilitating conditions entails aspects such as, technical infrastructure, material resources, and necessary knowledge to use it. Individuals that have access to adequate conditions are more likely to adopt ICT (Venkatesh et al., 2012). According to these authors facilitating conditions have a direct influence on both behavioral intention and use behavior. Therefore, we hypothesize:

H4a. The influence of facilitating conditions $(\mathrm{FC})$ on behavioral intention (BI) will be positive.

H4b. The influence of facilitating conditions (FC) on use behavior (UB) will be positive.

Hedonic motivation is conceptualized as the perceived pleasure derived from using a technology (Venkatesh et al., 2012). Earlier digital divide research found that entertainment purposes are important for ICT acceptance, especially for individuals with lower socioeconomic status (Bonfadelli, 2002; Hsieh et al., 2008). Van der Heijden (2004) concluded that perceived enjoyment is a stronger determinant of use intention. Therefore, we hypothesize:

H5. The influence of hedonic motivation (HM) on behavioral intention (BI) will be positive.

Price value is defined as the tradeoff between benefits and monetary value (Venkatesh et al., 2012). Price value is positive when the benefits of using the technology are perceived to be greater than the cost associated to it (Venkatesh et al., 2012). As shown in literature review, cost related factors have been one of the main drivers of uneven ICT adoption. However, given the potential value of ICT, the perceived benefits may be more important. For instance, in a study about web-enabled cell-phones (Setterstrom, Pearson, \& Orwig, 2013) it was found that perceived value had a positive influence on acceptance intention. Therefore, we hypothesize:

H6. The influence of price value (PV) on behavioral intention (BI) will be positive.

Habit refers to the extent which a person tends to perform a specific behavior automatically because of learning (Limayem, Hirt, \& Cheung, 2007; Venkatesh et al., 2012). The pervasiveness of ICT in many aspects of individuals' lives (e.g., professional, social, economic) may trigger the automatic behavior to use ICT. According to Venkatesh et al. (2012) habit has both a direct effect on use 
behavior and an indirect effect through intention, likewise, Baptista and Oliveira (2015) found that habit is significant in explaining mobile banking intention and use. Therefore, we hypothesize:

H7a. The influence of habit (HB) on behavioral intention (BI) will be positive.

H7b. The influence of habit (HB) on use behavior (UB) will be positive.

According to Venkatesh et al. (2003) behavioral intention has a positive influence on use behavior. Which is consistent with other theories as seen in literature review. Therefore, we hypothesize:

H8. The influence of behavioral intention (BI) on use behavior (UB) will be positive.

The use of ICT require certain knowledge and skills to be able to work with them (van Dijk, 2006). According to Pavlou and Fygenson (2006), personal skills and knowledge is a major antecedent of behavior. Moreover, according to ITU (2015), skills are critical to determine the effective use of ICT. ICT-related skills found to have positive effect on Internet use (Ferro et al., 2011). Therefore, we hypothesize:

H9. The influence of ICT skills (ICTS) on use behavior (UB) will be positive.

Drawing on the conceptual definitions from both the original and the refined theory of basic values, we identified values that may be particularly relevant to the context of ICT acceptance. Self-direction is defined as the independent thought and action of choosing, creating and exploring (Schwartz, 1992). It derives from autonomy and represents the creativity, freedom, and curiosity of an individual. The motivational goals behind stimulation are novelty, excitement and change in life (Schwartz, 1992). These two values fall under the openness to change grouping, which encourages pursuing new experiences, ideas and challenges. Due to the changing nature of technology, these values seem to relate positively to ICT acceptance. The sense of curiosity of both values is likely to relate with the willingness to try ICT, and the challenge goal behind stimulation may also affect the effective use of ICT. Bagchi et al. (2015) found that self-direction and stimulation positively correlated with Internet use. Therefore, we hypothesize:

H10. The influence of self-direction (SDT) on behavioral intention (BI) will be positive.

H11a. The influence of stimulation (ST) on behavioral intention (BI) will be positive.

H11b. The influence of stimulation (ST) on use behavior (UB) will be positive.

Hedonism emphasizes the pursuit of pleasure and enjoying life. It is defined as pleasure or sensuous gratification for oneself (Schwartz, 1992), thus it is conceptually different from hedonic motivation. ICT, more specifically Internet and mobile Internet, further social interactions and offer entertainment activities (van Deursen, van Dijk, \& Ten Klooster, 2015), which may be appealing for an individual who values enjoyment. Therefore, we hypothesize:

H12. The influence of hedonism (HE) on behavioral intention (BI) will be positive.

Grouped under self-enhancement, achievement and power are primarily concerned with one's own interests. Achievement is conceptualized as the personal success through the demonstration of competence according to social standards (Schwartz, 1992). It underlines social approval and expresses the desire to be judged by others as successful (Schwartz et al., 2012). Power represents the individual needs for dominance and control over people and resources (Schwartz, 1992). This suggests that people who value power are concerned with the pursuit of material goods and imposing one's will, while pursuing achievement can be seen as a way to promotes one's capabilities which can be related to the expectation of growth and personal development that ICT represents. Therefore, we hypothesize:

H13a. The influence of achievement $(A C)$ on behavioral intention (BI) will be positive. 
H13b. The influence of achievement (AC) on use behavior (UB) will be positive.

Contrasting with openness to change, there are conservation values, which stress self-restrictions, order and avoidance to change (Schwartz et al., 2012). The security value highlights safety of society and of self (Schwartz, 1992). Conformity is defined as restraint of actions and inclinations most likely to violate social expectations or norms (Schwartz, 1992). Tradition is related to commitment, respect and acceptance of ideas that culture or religion imposes (Schwartz, 1992). From the three, tradition has a strong opposition to openness to change, since it would limit autonomy and freedom (Schwartz et al., 2012). However, in the context of ICT, concerns about security may undermine their use. Security was considered important in e-government (Gupta, Dasgupta, \& Gupta, 2008), mobile banking (Wu \& Wang, 2005) and Internet use (Bagchi et al., 2015). Therefore, we hypothesize:

H14a. The influence of security (SE) on behavioral intention (BI) will be negative.

H14b. The influence of security (SE) on use behavior (UB) will be negative.

Self-transcendence values have a social focus. Benevolence emphasizes the preservation of the welfare of one's close group (Schwartz, 1992). It also promotes close emotional bonds and relationships. Universalism focuses more on tolerance and protection for the welfare of all people and for nature (Schwartz, 1992). Those who pursue self-transcendence values prefer the group at the expense of the individual, which suggests that they are less likely to adopt new technologies. Since, according to Bagchi et al. (2015) "individualism contributes to ICT adoption". Moreover, in the majority of developing countries personal interaction is considered very important. Therefore, we hypothesize:

H15a. The influence of benevolence (BE) on behavioral intention (BI) will be negative.

H15b. The influence of benevolence (BE) on use behavior (UB) will be negative.

$\mathrm{H16a}$. The influence of universalism (UN) on behavioral intention (BI) will be negative.

H16b. The influence of universalism (UN) on use behavior (UB) will be negative. 


\section{METHODOLOGY}

\subsection{MeASUREMENT}

An English questionnaire based on the research model was developed. The items and scale were adapted from prior literature. The UTAUT2 constructs were adapted from Venkatesh et al. (2012). Use behavior was adapted from Venkatesh, Brown, Maruping and Bala (2008) and both frequency and intensity of use were measured. The values constructs were adapted from Schwartz et al. (2012). A seven-point range scale anchored from totally disagree (1) to totally agree (7) was used to measure most of the items, with the exception of the Schwartz values items which used a six-point scale ranging from not like me at all (1) to very much like me (6). To measure ICT skills, the items of e-skills module of the EUROSTAT survey on ICT usage in households and by individual's version 3.2 were used. Yes-no questions were used to ask participants about the activities carried out in the last 12 months. For more details, please see Appendix B. Demographic questions about age, gender and education were also included. Age was measured in years. Gender was coded as a dummy variable where women were represented by 0 . Education was measured by degrees.

\subsection{DATA COLLECTION}

To test the research model, we collected data from Angola. Since the questionnaire was administrated in Portuguese, the official language of Angola, the items were independently translated by a professional translator. Empirical data was collected via a self-administrated survey, designed with the Portuguese version of the questionnaire. First, the survey was pretested among a group of 30 individuals who were not included in the final data. Preliminary analysis demonstrated that items were valid and reliable. Overall, we managed to collect 479 responses, from which after excluding incomplete cases, 245 were kept in the final sample. The common method bias was examined using Harman's one factor test (Podsakoff, MacKenzie, Lee, \& Podsakoff, 2003). The first factor explains $32.9 \%$ of variance, evidence of no significant common method bias. Further, we applied the marker variable technique (Lindell \& Whitney, 2001; Malhotra, Kim, \& Patil, 2006) to test for common method biases. No significant common method bias found in our dataset.

The respondents' characteristics are shown in Table 4.1. Males (76\%) outnumber females (24\%). The majority of the respondents were younger than 30 years old (78\%). Concerning education, more than $67 \%$ claimed to have a bachelor degree.

\begin{tabular}{lccc}
\hline \multicolumn{1}{c}{ Variable } & Value & Frequency & $\%$ \\
\hline Gender & Male & 186 & 75.9 \\
& Female & 59 & 24.1 \\
\hline \multirow{2}{*}{ Age } & $18-30$ & 191 & 78 \\
& $31-40$ & 32 & 13 \\
& $41-50$ & 19 & 7.8 \\
& $>51$ & 3 & 1.2 \\
\hline Education & Lower than Bachelor & 62 & 25.3 \\
& Bachelor & 166 & 67.8 \\
& Master or higher & 17 & 6.9 \\
\hline
\end{tabular}

Table 4.1 - Sample characteristics 


\section{RESULTS}

Partial least squares (PLS) was used to test the research model. PLS is a component-based approach to structural equation modeling (SEM) (Chin, 1998). This method is suitable for complex models and for prediction-oriented research (Hair, Ringle, \& Sarstedt, 2011; Henseler, Ringle, \& Sinkovics, 2009). Therefore, PLS can be considered appropriate for this study. Data analysis was conducted in two stages as recommended by Anderson and Gerbing (1988). First, the measurement model was examined to assess reliability and validity of the instrument, followed by the assessment of the structural model. SmartPLS 3 software (Ringle, Christian M., Wende, Sven, \& Becker, 2015) was used for this purpose.

\subsection{MeASUREMENT MODEL}

The measurement model was assessed regarding construct reliability, indicators reliability, convergent validity, and discriminant validity. The constructs were modelled using reflective indicators.

The results of the measurement model are presented in Table 5.1 and 5.2. To evaluate internal consistency reliability two measures can be used, Cronbach's alpha and composite reliability (CR). Cronbach's alpha provides an estimate for reliability based on the indicators intercorrelations and assumes that all indicators are equally reliable (Henseler et al., 2009). Unlike Cronbach's alpha, CR takes into account that indicators have different loadings, thus making it more appropriate for PLS, which prioritizes indicators according to their reliability (Hair et al., 2011; Henseler et al., 2009). As seen in Table 5.1, all composite reliability values are higher than 0.70 , providing evidence of construct reliability. Individual indicator reliability was evaluated based on factor loadings, which should preferably be higher than 0.70 (Chin, 1998) and indicators with loadings below 0.40 should be eliminated (Hair et al., 2011). Based on Table 5.1 we can conclude that indicators reliability is adequate.

Values of the average variance extracted (AVE) are above 0.50 , meaning that the latent variable explains more than half of variance of its indicators (Hair et al., 2011; Henseler et al., 2009). Thus, ensuring convergent validity. Discriminant validity was assessed using three criteria. First, the square root of AVE should be greater than the correlations between constructs (Fornell \& Larcker, 1981; Henseler et al., 2009). As seen in Table 5.2, the square roots of AVE (diagonal elements) are greater than inter-constructs correlations (off-diagonal elements). Second, each indicator's loading should be higher than all cross-loadings (Chin, 1998; Henseler et al., 2009). This criterion was also met, as shown in Table 5.1. Finally, heterotrait-monotrait ratio (HTMT) should be lower than 0.90 (Henseler, Ringle, \& Sarstedt, 2015). This criteria was also achieved (please, see Appendix C). 


\begin{tabular}{|c|c|c|c|c|c|c|c|c|c|c|c|c|c|c|c|c|c|}
\hline Construct & & PE & $\mathrm{EE}$ & SI & FC & HM & PV & $\mathrm{HB}$ & BI & UB & SDT & ST & HE & $A C$ & SE & $\mathrm{BE}$ & UN \\
\hline \multirow{4}{*}{$\begin{array}{c}\text { Performance } \\
\text { Expectancy (PE) } \\
\text { CR=0.858 }\end{array}$} & PE1 & 0.780 & 0.251 & 0.303 & 0.204 & 0.352 & 0.177 & 0.388 & 0.359 & 0.198 & 0.216 & 0.103 & 0.216 & 0.109 & 0.161 & 0.216 & 0.209 \\
\hline & PE2 & 0.691 & 0.268 & 0.291 & 0.128 & 0.365 & 0.121 & 0.308 & 0.240 & 0.094 & 0.136 & 0.097 & 0.083 & 0.008 & 0.093 & 0.164 & 0.076 \\
\hline & PE3 & 0.846 & 0.153 & 0.426 & 0.214 & 0.382 & 0.259 & 0.404 & 0.423 & 0.155 & 0.300 & 0.177 & 0.240 & 0.118 & 0.180 & 0.399 & 0.275 \\
\hline & PE4 & 0.783 & 0.317 & 0.418 & 0.234 & 0.290 & 0.252 & 0.370 & 0.360 & 0.274 & 0.270 & 0.172 & 0.165 & 0.213 & 0.105 & 0.153 & 0.105 \\
\hline \multirow{3}{*}{$\begin{array}{l}\text { Effort Expectancy } \\
\qquad \begin{array}{c}(\mathrm{EE}) \\
\mathrm{CR}=0.826\end{array}\end{array}$} & EE2 & 0.194 & 0.824 & 0.300 & 0.477 & 0.292 & 0.121 & 0.329 & 0.208 & 0.255 & 0.120 & 0.237 & 0.047 & 0.204 & 0.055 & 0.093 & 0.104 \\
\hline & EE3 & 0.118 & 0.634 & 0.191 & 0.363 & 0.174 & 0.145 & 0.192 & 0.096 & 0.077 & 0.113 & 0.181 & 0.087 & 0.096 & 0.095 & 0.074 & 0.144 \\
\hline & EE4 & 0.347 & 0.876 & 0.331 & 0.477 & 0.263 & 0.162 & 0.399 & 0.253 & 0.268 & 0.242 & 0.281 & 0.088 & 0.112 & 0.094 & 0.146 & 0.116 \\
\hline \multirow{3}{*}{$\begin{array}{l}\text { Social Influence } \\
\text { (SI) } \\
\text { CR }=0.891\end{array}$} & SI1 & 0.364 & 0.282 & 0.848 & 0.200 & 0.331 & 0.139 & 0.326 & 0.217 & 0.083 & 0.221 & 0.195 & 0.176 & 0.170 & 0.185 & 0.280 & 0.223 \\
\hline & $S 12$ & 0.442 & 0.264 & 0.902 & 0.151 & 0.311 & 0.172 & 0.396 & 0.237 & 0.091 & 0.214 & 0.219 & 0.136 & 0.209 & 0.130 & 0.168 & 0.212 \\
\hline & $S 13$ & 0.395 & 0.390 & 0.813 & 0.199 & 0.287 & 0.167 & 0.352 & 0.213 & 0.108 & 0.245 & 0.169 & 0.168 & 0.157 & 0.043 & 0.188 & 0.033 \\
\hline \multirow{3}{*}{$\begin{array}{c}\text { Facilitating } \\
\text { Conditions (FC) } \\
\text { CR }=0.783\end{array}$} & FC2 & 0.109 & 0.487 & 0.114 & 0.685 & 0.176 & 0.150 & 0.246 & 0.164 & 0.287 & 0.132 & 0.210 & 0.038 & 0.188 & 0.086 & 0.132 & 0.079 \\
\hline & FC3 & 0.191 & 0.413 & 0.175 & 0.807 & 0.230 & 0.102 & 0.340 & 0.311 & 0.294 & 0.289 & 0.358 & 0.161 & 0.205 & 0.182 & 0.197 & 0.189 \\
\hline & FC4 & 0.248 & 0.371 & 0.173 & 0.722 & 0.392 & 0.197 & 0.262 & 0.406 & 0.202 & 0.345 & 0.257 & 0.190 & 0.128 & 0.321 & 0.327 & 0.268 \\
\hline \multirow{3}{*}{$\begin{array}{c}\text { Hedonic } \\
\text { Motivations (HM) } \\
\text { CR }=0.898\end{array}$} & HM1 & 0.343 & 0.300 & 0.397 & 0.292 & 0.872 & 0.093 & 0.390 & 0.379 & 0.142 & 0.348 & 0.317 & 0.348 & 0.205 & 0.271 & 0.368 & 0.234 \\
\hline & HM2 & 0.299 & 0.253 & 0.265 & 0.281 & 0.837 & 0.129 & 0.392 & 0.349 & 0.152 & 0.259 & 0.220 & 0.299 & 0.174 & 0.229 & 0.340 & 0.149 \\
\hline & HM3 & 0.473 & 0.270 & 0.282 & 0.374 & 0.880 & 0.126 & 0.375 & 0.485 & 0.214 & 0.348 & 0.273 & 0.338 & 0.191 & 0.380 & 0.460 & 0.305 \\
\hline \multirow{3}{*}{$\begin{array}{l}\text { Price Value (PV) } \\
\qquad C R=0.807\end{array}$} & PV1 & 0.081 & 0.192 & 0.064 & 0.133 & 0.017 & 0.676 & 0.155 & 0.053 & 0.136 & -0.003 & 0.102 & 0.093 & 0.075 & 0.045 & 0.005 & -0.010 \\
\hline & PV2 & 0.147 & 0.200 & 0.166 & 0.194 & 0.058 & 0.740 & 0.260 & 0.088 & 0.209 & 0.043 & 0.128 & 0.071 & 0.150 & 0.078 & 0.027 & 0.048 \\
\hline & PV3 & 0.291 & 0.095 & 0.167 & 0.154 & 0.160 & 0.867 & 0.256 & 0.175 & 0.189 & 0.204 & 0.078 & 0.074 & 0.109 & 0.150 & 0.163 & 0.071 \\
\hline \multirow{4}{*}{$\begin{array}{l}\text { Habit (HB) } \\
C R=0.838\end{array}$} & HB1 & 0.342 & 0.440 & 0.327 & 0.356 & 0.383 & 0.240 & 0.790 & 0.381 & 0.303 & 0.399 & 0.248 & 0.139 & 0.124 & 0.225 & 0.315 & 0.237 \\
\hline & HB2 & 0.250 & 0.254 & 0.253 & 0.206 & 0.185 & 0.192 & 0.682 & 0.243 & 0.304 & 0.106 & 0.258 & 0.024 & 0.149 & -0.015 & 0.060 & -0.001 \\
\hline & HB3 & 0.447 & 0.117 & 0.356 & 0.230 & 0.402 & 0.249 & 0.698 & 0.426 & 0.187 & 0.276 & 0.182 & 0.313 & 0.134 & 0.257 & 0.304 & 0.148 \\
\hline & HB4 & 0.382 & 0.405 & 0.321 & 0.344 & 0.345 & 0.221 & 0.828 & 0.378 & 0.369 & 0.308 & 0.269 & 0.101 & 0.167 & 0.193 & 0.213 & 0.129 \\
\hline \multirow{3}{*}{$\begin{array}{c}\text { Behavioral } \\
\text { Intention (BI) } \\
\text { CR }=0.868\end{array}$} & BI1 & 0.317 & 0.155 & 0.124 & 0.338 & 0.447 & 0.061 & 0.309 & 0.768 & 0.226 & 0.301 & 0.186 & 0.264 & 0.121 & 0.317 & 0.471 & 0.418 \\
\hline & $\mathrm{B} 12$ & 0.351 & 0.257 & 0.228 & 0.367 & 0.395 & 0.159 & 0.418 & 0.869 & 0.273 & 0.324 & 0.302 & 0.311 & 0.173 & 0.307 & 0.430 & 0.329 \\
\hline & BI3 & 0.458 & 0.224 & 0.287 & 0.327 & 0.350 & 0.179 & 0.458 & 0.848 & 0.362 & 0.280 & 0.274 & 0.307 & 0.254 & 0.255 & 0.375 & 0.335 \\
\hline
\end{tabular}

Table 5.1 - Loadings and Cross-Loadings 
(Table 5.1 Continued)

\begin{tabular}{|c|c|c|c|c|c|c|c|c|c|c|c|c|c|c|c|c|c|}
\hline Construct & & PE & $\mathrm{EE}$ & SI & FC & HM & PV & HB & BI & UB & SDT & ST & $\mathrm{HE}$ & AC & SE & BE & UN \\
\hline \multirow{3}{*}{$\begin{array}{l}\text { Use Behavior (UB) } \\
\qquad \mathrm{CR}=0.908\end{array}$} & U2 & 0.162 & 0.265 & 0.098 & 0.281 & 0.241 & 0.228 & 0.346 & 0.355 & 0.857 & 0.224 & 0.160 & 0.190 & 0.165 & 0.155 & 0.096 & 0.070 \\
\hline & U3 & 0.229 & 0.252 & 0.117 & 0.309 & 0.181 & 0.216 & 0.359 & 0.297 & 0.889 & 0.219 & 0.173 & 0.126 & 0.271 & 0.166 & 0.102 & 0.126 \\
\hline & U4 & 0.233 & 0.227 & 0.075 & 0.321 & 0.109 & 0.169 & 0.318 & 0.267 & 0.881 & 0.078 & 0.163 & 0.070 & 0.216 & 0.086 & -0.039 & 0.056 \\
\hline \multirow{2}{*}{$\begin{array}{l}\text { Self-direction (SDT) } \\
\qquad C R=0.821\end{array}$} & SDT1 & 0.344 & 0.200 & 0.284 & 0.312 & 0.348 & 0.160 & 0.369 & 0.290 & 0.155 & 0.819 & 0.337 & 0.266 & 0.191 & 0.351 & 0.471 & 0.303 \\
\hline & SDT2 & 0.177 & 0.159 & 0.162 & 0.293 & 0.278 & 0.102 & 0.260 & 0.315 & 0.171 & 0.850 & 0.269 & 0.304 & 0.260 & 0.331 & 0.359 & 0.262 \\
\hline \multirow{2}{*}{$\begin{array}{c}\text { Stimulation (ST) } \\
\quad C R=0.758\end{array}$} & ST1 & 0.167 & 0.254 & 0.186 & 0.369 & 0.244 & 0.156 & 0.263 & 0.224 & 0.146 & 0.369 & 0.756 & 0.227 & 0.186 & 0.215 & 0.322 & 0.196 \\
\hline & ST2 & 0.119 & 0.222 & 0.172 & 0.230 & 0.247 & 0.038 & 0.235 & 0.256 & 0.149 & 0.204 & 0.806 & 0.186 & 0.145 & 0.087 & 0.190 & 0.140 \\
\hline \multirow{2}{*}{$\begin{array}{c}\text { Hedonism (HE) } \\
\quad \mathrm{CR}=0.846\end{array}$} & HE1 & 0.250 & 0.102 & 0.150 & 0.210 & 0.345 & 0.095 & 0.207 & 0.328 & 0.152 & 0.286 & 0.253 & 0.881 & 0.265 & 0.212 & 0.209 & 0.149 \\
\hline & HE2 & 0.150 & 0.046 & 0.170 & 0.104 & 0.307 & 0.066 & 0.119 & 0.279 & 0.095 & 0.303 & 0.193 & 0.831 & 0.306 & 0.267 & 0.240 & 0.170 \\
\hline \multirow{2}{*}{$\begin{array}{l}\text { Achievement (AC) } \\
\quad \mathrm{CR}=0.779\end{array}$} & AC1 & 0.070 & 0.133 & 0.176 & 0.211 & 0.216 & 0.040 & 0.154 & 0.139 & 0.204 & 0.202 & 0.193 & 0.227 & 0.763 & 0.132 & 0.077 & 0.081 \\
\hline & AC2 & 0.170 & 0.147 & 0.162 & 0.164 & 0.143 & 0.179 & 0.152 & 0.213 & 0.194 & 0.231 & 0.148 & 0.298 & 0.834 & 0.278 & 0.111 & 0.027 \\
\hline \multirow{6}{*}{$\begin{array}{l}\text { Security (SE) } \\
C R=0.892\end{array}$} & SEP1 & 0.109 & 0.085 & 0.053 & 0.207 & 0.133 & 0.013 & 0.080 & 0.230 & 0.042 & 0.148 & 0.100 & 0.107 & 0.061 & 0.645 & 0.270 & 0.322 \\
\hline & SEP2 & 0.190 & 0.065 & 0.137 & 0.185 & 0.359 & 0.096 & 0.200 & 0.276 & 0.153 & 0.358 & 0.179 & 0.261 & 0.201 & 0.835 & 0.429 & 0.258 \\
\hline & SEP3 & 0.170 & 0.069 & 0.173 & 0.206 & 0.235 & 0.074 & 0.154 & 0.295 & 0.086 & 0.277 & 0.135 & 0.224 & 0.189 & 0.790 & 0.370 & 0.353 \\
\hline & SES1 & 0.172 & 0.144 & 0.162 & 0.257 & 0.351 & 0.177 & 0.259 & 0.325 & 0.140 & 0.445 & 0.212 & 0.284 & 0.287 & 0.832 & 0.390 & 0.396 \\
\hline & SES2 & 0.101 & 0.052 & 0.079 & 0.207 & 0.295 & 0.113 & 0.189 & 0.227 & 0.191 & 0.321 & 0.112 & 0.248 & 0.266 & 0.748 & 0.232 & 0.293 \\
\hline & SES3 & 0.049 & 0.017 & -0.001 & 0.229 & 0.172 & 0.145 & 0.133 & 0.241 & 0.066 & 0.255 & 0.099 & 0.091 & 0.157 & 0.705 & 0.358 & 0.407 \\
\hline \multirow{3}{*}{$\begin{array}{c}\text { Benevolence (BE) } \\
\quad C R=0.869\end{array}$} & BE1 & 0.300 & 0.139 & 0.167 & 0.276 & 0.407 & 0.117 & 0,276 & 0.465 & 0.013 & 0.437 & 0.283 & 0.249 & 0.078 & 0.424 & 0.874 & 0.406 \\
\hline & BE2 & 0.275 & 0.031 & 0.168 & 0.270 & 0.379 & 0.140 & 0.239 & 0.426 & 0.030 & 0.449 & 0.299 & 0.207 & 0.092 & 0.428 & 0.890 & 0.388 \\
\hline & BE3 & 0.199 & 0.182 & 0.291 & 0.217 & 0.353 & 0.044 & 0.243 & 0.374 & 0.112 & 0.337 & 0.217 & 0.188 & 0.130 & 0.260 & 0.716 & 0.373 \\
\hline \multirow{3}{*}{$\begin{array}{c}\text { Universalism (UN) } \\
\quad C R=0.818\end{array}$} & UN1 & 0.232 & 0.128 & 0.203 & 0.251 & 0.321 & 0.073 & 0.188 & 0.396 & 0.120 & 0.306 & 0.212 & 0.177 & 0.119 & 0.389 & 0.467 & 0.852 \\
\hline & UN2 & 0.154 & 0.114 & 0.093 & 0.123 & 0.134 & 0.030 & 0.096 & 0.273 & 0.020 & 0.230 & 0.146 & 0.058 & 0.043 & 0.243 & 0.247 & 0.682 \\
\hline & UN3 & 0.134 & 0.091 & 0.117 & 0.200 & 0.151 & 0.038 & 0.117 & 0.324 & 0.063 & 0.242 & 0.130 & 0.176 & -0.027 & 0.375 & 0.342 & 0.784 \\
\hline
\end{tabular}

Notes: PE: performance expectancy; EE: effort expectancy; SI: social influence; FC: facilitating conditions; HM: hedonic motivation; PV: price value; HB: habit; BI: behavioral intention

UB: use behavior; SDT: self-direction; ST: stimulation; HE: hedonism; AC: achievement; SE: security; BE: benevolence; UN: Universalism 


\begin{tabular}{|c|c|c|c|c|c|c|c|c|c|c|c|c|c|c|c|c|c|c|c|}
\hline & Mean & SD & PE & $\mathrm{EE}$ & SI & FC & $\mathrm{HM}$ & PV & HB & BI & UB & ICTS & SDT & ST & HE & $A C$ & SE & BE & UN \\
\hline $\mathrm{PE}$ & 6.318 & 0.911 & 0.777 & & & & & & & & & & & & & & & & \\
\hline $\mathrm{EE}$ & 5.428 & 1.310 & 0.307 & 0.785 & & & & & & & & & & & & & & & \\
\hline $\mathrm{FC}$ & 5.892 & 1.072 & 0.257 & 0.561 & 0.213 & 0.740 & & & & & & & & & & & & & \\
\hline $\mathrm{HM}$ & 6.390 & 0.967 & 0.442 & 0.317 & 0.362 & 0.372 & 0.863 & & & & & & & & & & & & \\
\hline PV & 4.062 & 1.500 & 0.270 & 0.176 & 0.187 & 0.202 & 0.135 & 0.765 & & & & & & & & & & & \\
\hline $\mathrm{BI}$ & 6.405 & 0.849 & 0.456 & 0.256 & 0.260 & 0.414 & 0.477 & 0.163 & 0.480 & 0.829 & & & & & & & & & \\
\hline UB & 5.674 & 1.372 & 0.238 & 0.282 & 0.110 & 0.347 & 0.201 & 0.233 & 0.389 & 0.349 & 0.876 & & & & & & & & \\
\hline ICTS & 7.641 & 2.111 & 0.140 & 0.171 & -0.008 & 0.209 & 0.123 & 0.079 & 0.213 & 0.168 & 0.330 & NA & & & & & & & \\
\hline SDT & 5.446 & 0.765 & 0.308 & 0.214 & 0.264 & 0.362 & 0.373 & 0.155 & 0.374 & 0.363 & 0.196 & 0.100 & 0.835 & & & & & & \\
\hline ST & 5.057 & 1.011 & 0.181 & 0.303 & 0.228 & 0.378 & 0.314 & 0.120 & 0.317 & 0.308 & 0.189 & -0.023 & 0.361 & 0.781 & & & & & \\
\hline $\mathrm{HE}$ & 5.529 & 0.734 & 0.238 & 0.089 & 0.186 & 0.188 & 0.381 & 0.096 & 0.194 & 0.356 & 0.146 & 0.026 & 0.342 & 0.263 & 0.856 & & & & \\
\hline$A C$ & 4.623 & 1.262 & 0.154 & 0.176 & 0.210 & 0.231 & 0.220 & 0.144 & 0.190 & 0.223 & 0.247 & 0.060 & 0.272 & 0.210 & 0.331 & 0.799 & & & \\
\hline $\mathrm{BE}$ & 5.596 & 0.708 & 0.314 & 0.139 & 0.246 & 0.308 & 0.459 & 0.123 & 0.305 & 0.510 & 0.059 & 0.081 & 0.494 & 0.323 & 0.260 & 0.119 & 0.452 & 0.831 & \\
\hline UN & 5.449 & 0.780 & 0.228 & 0.143 & 0.185 & 0.255 & 0.275 & 0.064 & 0.179 & 0.433 & 0.095 & 0.142 & 0.338 & 0.213 & 0.185 & 0.065 & 0.440 & 0.468 & 0.776 \\
\hline
\end{tabular}

Notes: Diagonal elements are square root of the AVEs and off-diagonal elements are correlations.

PE: performance expectancy; EE: effort expectancy; SI: social influence; FC: facilitating conditions; HM: hedonic motivation; PV: price value; HB: habit;

BI: behavioral intention; UB: use behavior; ICTS: ICT skills; SDT: self-direction; ST: stimulation; HE: hedonism; AC: achievement; SE: security; BE: benevolence; UN: universalism.

Table 5.2 - Descriptive statistics, correlations and AVEs 


\subsection{STRUCTURAL MODEL}

The assessment of the structural model was done using three models (1) UTAUT2, (2) Schwartz's basic values, and (3) combined model (UTAUT2 + basic values + ICT skills - research model). The path significances were estimated using a bootstrapping resampling technique with 5,000 iterations (Hair et al., 2011). Coefficient of determination $\left(R^{2}\right)$ and adjusted $R^{2}$ of the dependent variables, path significances, and their respective significance levels are presented in Table 5.3.

\begin{tabular}{|c|c|c|c|c|c|}
\hline & UTAUT2 & Basic values & UTAUT2 + Basic values + Skills & Hypotheses & Conclusion \\
\hline \multicolumn{6}{|l|}{ Behavioral Intention (BI) } \\
\hline$R^{2}$ & 0.392 & 0.373 & 0.504 & & \\
\hline Adjusted $\mathrm{R}^{2}$ & 0.374 & 0.355 & 0.474 & & \\
\hline Performance Expectancy (PE) & $0.240 * * *$ & -- & $0.194 * * *$ & $\mathrm{H} 1$ & Supported \\
\hline Effort Expectancy (EE) & -0.108 & -- & -0.053 & $\mathrm{H} 2$ & Not supported \\
\hline Social Influence (SI) & -0.041 & -- & -0.080 & $\mathrm{H} 3$ & Not supported \\
\hline Facilitating Conditions (FC) & $0.252^{* * *}$ & -- & $0.161^{* *}$ & $\mathrm{H} 4 \mathrm{a}$ & Supported \\
\hline Hedonic Motivation (HM) & $0.221 * * *$ & -- & 0.081 & H5 & Not supported \\
\hline Price Value (PV) & -0.027 & -- & -0.031 & $\mathrm{H} 6$ & Not supported \\
\hline Habit (HB) & $0.242 * * *$ & -- & $0.239 * * *$ & $\mathrm{H} 7 \mathrm{a}$ & Supported \\
\hline Self-direction (SDT) & -- & 0.014 & -0.081 & $\mathrm{H} 10$ & Not supported \\
\hline Stimulation (ST) & -- & 0.089 & 0.017 & $\mathrm{H} 11 \mathrm{a}$ & Not supported \\
\hline Hedonism (HE) & -- & $0.172 * *$ & $0.135 *$ & $\mathrm{H} 12$ & Supported \\
\hline Achievement (AC) & -- & 0.085 & 0.058 & $\mathrm{H} 13 \mathrm{a}$ & Not supported \\
\hline Security (SE) & -- & 0.025 & -0.001 & $\mathrm{H} 14 \mathrm{a}$ & Not supported \\
\hline Benevolence (BE) & -- & $0.308^{* * *}$ & $0.220 * * *$ & $\mathrm{H} 15 \mathrm{a}$ & Not supported \\
\hline Universalism (UN) & -- & $0.218^{* * *}$ & $0.200 * * *$ & $\mathrm{H} 16 \mathrm{a}$ & Not supported \\
\hline \multicolumn{6}{|l|}{ Use Behavior (UB) } \\
\hline $\mathrm{R}^{2}$ & 0.215 & 0.183 & 0.311 & & \\
\hline Adjusted $\mathrm{R}^{2}$ & 0.205 & 0.162 & 0.284 & & \\
\hline Behavioral Intention (BI) & $0.158^{*}$ & $0.377^{* * *}$ & $0.224^{* *}$ & $\mathrm{H} 8$ & Supported \\
\hline Facilitating Conditions (FC) & $0.188^{* *}$ & -- & $0.150 *$ & $\mathrm{H} 4 \mathrm{~b}$ & Supported \\
\hline Habit (HB) & $0.241 * * *$ & -- & $0.200 * * *$ & $\mathrm{H} 7 \mathrm{~b}$ & Supported \\
\hline Stimulation (ST) & -- & 0.099 & 0.049 & $\mathrm{H} 11 \mathrm{~b}$ & Not supported \\
\hline Achievement (AC) & -- & $0.150 * *$ & $0.126^{*}$ & $\mathrm{H} 13 \mathrm{~b}$ & Supported \\
\hline Security (SE) & -- & 0.068 & 0.001 & $\mathrm{H} 14 \mathrm{~b}$ & Not supported \\
\hline Benevolence (BE) & -- & $-0.195 * *$ & $-0.196 * *$ & $\mathrm{H} 15 \mathrm{~b}$ & Supported \\
\hline Universalism (UN) & -- & -0.038 & -0.036 & $\mathrm{H} 16 \mathrm{~b}$ & Not supported \\
\hline ICT Skills & -- & -- & $0.233^{* * *}$ & $\mathrm{H} 9$ & Supported \\
\hline
\end{tabular}

Notes: ${ }^{*} p<0.10 ;{ }^{* *} p<0.05 ;{ }^{* * *} p<0.01$

Table 5.3 - Structural model results

The adjusted $R^{2}$, which accounts for the number of independent variables included in the model (Niehaves \& Plattfaut, 2014), was used to evaluate the models. The adjusted $\mathrm{R}^{2}$ for UTAUT2 model, Schwartz's basic values model, and for UTAUT2 + basic values + ICT skills model (conceptual model proposed) are respectively, $0.374,0.355$, and 0.474 for behavioral intention and $0.205,0.162$, and 0.284 for use behavior. This suggests that the theoretical model proposed is best, for this reason, the remainder of the paper is based on the final model (i.e. UTAUT2 + basic values + ICT skills model). 
The model explains $50.4 \%$ of the variation in behavioral intention and $31.1 \%$ of the variation in use behavior.

To explain behavioral intention, performance expectancy, facilitating conditions, habit, and hedonism were found to be statistically significant, thus supporting hypotheses $\mathrm{H} 1, \mathrm{H} 4 \mathrm{a}, \mathrm{H} 7 \mathrm{a}$, and H12. Effort expectancy, social influence, price value, and hedonic motivation were not statistically significant, therefore $\mathrm{H} 2, \mathrm{H} 3, \mathrm{H} 5$, and $\mathrm{H} 6$ are not supported. In the same way, self-direction, stimulation, achievement, and security were found to be not significant in explaining behavioral intention, not supporting $\mathrm{H} 10, \mathrm{H} 11 \mathrm{a}, \mathrm{H} 13 \mathrm{a}$, and $\mathrm{H} 14 \mathrm{a}$. Benevolence and universalism were statistically significant, however, we hypothesized that they would negatively influence behavioral intention. As shown in Table 5.3, these variables had an unexpected sign, thus H15a and H16a are not supported.

Behavioral intention, facilitating conditions, habit, achievement, benevolence, and ICT skills were all found to be statistically significant in explaining use behavior. Consequently, supporting hypotheses $\mathrm{H} 4 \mathrm{~b}, \mathrm{H} 7 \mathrm{~b}, \mathrm{H} 8, \mathrm{H} 9, \mathrm{H} 13 \mathrm{~b}$, and $\mathrm{H} 15 \mathrm{~b}$. Stimulation, security and universalism did not have a significant effect over use behavior. Therefore, hypotheses H11b, H14b, and H16b are not supported. Overall, ten of the twenty-three hypotheses were supported. 


\section{DISCUSSION}

The research model explains $50.4 \%$ of behavioral intention variation. In determining behavioral intention performance expectancy, facilitating conditions, habit, hedonism, benevolence, and universalism were significant. In turn, ICT use behavior (31.1\% of variation explained) was found to be mainly influenced by ICT skills, habit, benevolence (negatively), and behavioral intention. With a low magnitude, facilitating conditions and achievement also exerted influence on ICT use behavior.

The performance expectancy finding is consistent with earlier studies (Niehaves \& Plattfaut, 2014; Venkatesh et al., 2012) and reflects the importance of utilitarian functions of ICT. This finding is also in line with prior digital divide research (e.g., Bonfadelli, 2002; Eamon, 2004), that considers utilitarian outcomes a major driver of ICT acceptance, especially for those with higher educational levels. Facilitating conditions was significant in explaining both behavioral intention and use behavior. This suggests that respondents consider resources and support to be important to ICT acceptance. Habit had a strong influence over both behavioral intention and use behavior, thus suggesting that once ICT use becomes a routine, individuals are more likely to use it. The results also validated the relationship between behavioral intention and use behavior, this is consistent with earlier research (Ajzen, 1991; Venkatesh et al., 2003, 2012) that considers intention an important antecedent of use behavior. Hedonism was found to positively influence behavioral intention, while hedonic motivation was not. This indicates that leisure and entertainment are considered important factors concerning ICT acceptance, which is in line with prior studies (e.g., Brown \& Venkatesh, 2005; Niehaves \& Plattfaut, 2014). Moreover, this finding also reveals that more important than enjoyment derived from using a specific technology, is enjoyment in a broader sense. Hence, one's characteristic overcomes the technology one. Contrary to what was expected, benevolence and universalism had a positive influence over behavioral intention. Both of these values emphasize welfare of others. Hence, individuals who value welfare of people in general, are more likely to try ICT. Regarding use behavior, two values conflict with each other. Valuing demonstration of personal success (achievement) is perceived by the respondents to foster ICT use, while valuing benevolence, which focuses on personal bonds and human-to-human interactions is perceived to limit actual ICT use. This is consistent with the postulated conflicts between values (Schwartz, 2012). ICT skills was one of the most important factors in explaining use behavior, confirming the idea that skills are essential to successfully and effectively use ICT (Ghobadi \& Ghobadi, 2013; van Dijk, 2006). This finding also provides support for the argument that inequalities regarding ICT use are mainly driven by individuals' skills.

The results did not validate some UTAUT2 relationships. For instance, effort expectancy, the degree of ease associated to ICT use had no significant influence on behavioral intention. Thus, contradicting prevailing argument that technology use depends on the perception of how easy its use is (Agarwal \& Karahanna, 2000; Hsieh et al., 2008). Price value had no significant importance, probably due to the fact that in Africa, the price of ICT remains very high (Bornman, 2016; ITU, 2015). Therefore, people do not consider it to be a fair tradeoff between the cost and benefits. Which, suggests that cost remains a strong barrier to ICT acceptance, consequently, contributing to digital divide. While some studies (Gupta et al., 2008; Niehaves \& Plattfaut, 2014; Venkatesh \& Brown, 2001) highlighted the importance of social influence in forming behavioral intention, the results suggest that individuals are not influenced by significant others, which is probably due to the fact that the data was collected 
in urban areas where social ties are weaker than in rural environments. A similar argument was used by Chen et al. (2010) when analyzing China's rural digital divide. No evidence was found to support the relationship between self-direction, stimulation, and security with ICT acceptance, thus suggesting that values that encourage autonomy (self-direction) and challenge in life (stimulation) may not be considered important. According to ITU (2015), African countries are far behind as regards ICT, therefore, individuals may not yet, perceive some of the security risks that can be related to ICT. We believe that further examination of basic values on ICT acceptance is needed to clarify some of the findings.

\subsection{THEORETICAL IMPLICATIONS}

This study contributes to the stream of research that addresses individual-level digital divide from a technology adoption approach, by extending to the context of a sub-Saharan country, also by incorporating new constructs. To the best of the authors' knowledge, it is the first attempt that combines UTAUT2, Schwartz's basic values, and ICT skills in the context of ICT acceptance/digital divide. In particular, research on digital divide has been increasingly focused on the necessary knowledge and skills to effectively use ICT (e.g., Ferro et al., 2011; van Deursen \& van Dijk, 2015; van Dijk, 2006). Thus, by incorporating ICT skills, this research provides evidence that ICT skills represent a key factor to ensuring individual-level ICT acceptance.

Another important aspect involves the addition of a major social sciences concept, values, in the research model. In doing so, this study responds to the call for a deeper analysis of complementary causes (social, cultural, psychological) behind ICT inequalities (van Dijk, 2006). Four basic values (hedonism, achievement, benevolence, and universalism) exerted significant influence on ICT acceptance. Therefore, we can argue that basic values, can provide new insights into the subject. The findings reveal that use behavior was shaped by two conflicting value dimensions, self-transcendence versus self-enhancement. More interestingly perhaps, is the role of benevolence, which positively influenced ICT behavioral intention and negatively influenced use behavior. Demonstrating that it can either promote or inhibit ICT acceptance.

Our findings also contribute to technology adoption research, specifically, with regard to UTAUT2. We tested the set of constructs in a new cultural setting, thus extending its generalizability. We found that habit was the most important factor influencing ICT behavioral intention, as also use behavior.

\subsection{PRACTICAL IMPLICATIONS}

From a practical perspective, understanding which factors affect individual-level ICT acceptance is crucial to plan and implement more appropriate initiatives toward bridging the digital divide. Based on our set of findings, we suggest different strategies that could benefit policy-makers, more specifically, those of developing countries.

Our study reveals that ICT skills is a key factor determining ICT use behavior. Therefore, it is important to enhance individuals' skills. This could be achieved by establishing kiosks or Community Technology Centers specially designed to provide access to ICT, which is still necessary, but especially, training programs, support, and guidance to the general population, in order to improve skills and to encourage habitual ICT use. It is questionable whether this kind of initiative guarantees 
actual ICT use. However, this approach might be more effective than, for instance, ICT subsidization. Hence the latter implies that individuals acquire knowledge and skills and form usage habits independently. Thus making it more suitable for those who value openness to change. Furthermore, policies favoring collaboration between the school system and the ICT private sector, where the latter provides the necessary material resources, would promote ICT acceptance and would have a substantial impact on the ICT skills issue. Taking as an example the New Partnership for Africa Development (NEPAD) e-schools initiative that intends to improve ICT skills of young Africans in primary and secondary schools (Farrell, Isaacs, \& Trucano, 2007).

Spreading information regarding ICT and its potential benefits is also important. Policy-makers and organizations involved in ICT acceptance, should launch awareness campaigns that emphasize distinct purposes such as, performance expectancy, hedonism, and achievement. Besides, increasing general understanding of ICT and its impact on development of the society, it could be an effective way to attract individuals who value benevolence, to use ICT.

Results imply that cost also plays a substantial role on ICT acceptance, therefore greater efforts should be made to lower ICT prices. One possible way to achieve it, is through policies emphasizing market regulation (ITU, 2015). Finally, ongoing research to measure and monitor ICT acceptance, is of further importance (Bornman, 2016). In summary, efforts to promote ICT acceptance and consequently bridge the digital divide would require a multifaceted approach focusing on: awareness, providing access, improving ICT skills, and cost reduction.

\subsection{LIMITATIONS AND FUTURE RESEARCH}

There are some limitations that must be acknowledged. First, the generalizability of the results may be limited to a specific time and geographic region as we conducted a cross-sectional research. The data was collected in urban areas; therefore the results may not reflect the reality of rural and remote locations that are less technologically advanced. Longitudinal studies that examine if the factors change over time would provide interesting insights. Future studies should also consider collecting data across the whole country. Second, ICT skills were measured using a self-reported method. Some authors (Hargittai, 2005; van Deursen, Helsper, \& Eynon, 2016) believe that selfreported measures may not reflect the reality of the individuals' skills, since this can lead to overrated or underrated skills. Future research can address this limitation by using a controlled setting to measure individuals' ICT skills. Two final recommendations for future studies: given the importance of ICT skills, future research might analyze different skill types (e.g., information, technical, communication) to provide a more detailed understanding of how skills affect ICT use; including demographic variables (e.g., age, gender, geographic region, education, and income) to examine ICT acceptance between different socio-demographic groups would be of great interest. 


\section{CONCLUSIONS}

Inequalities of access and use of ICT prevents certain groups of individuals to fully explore the development opportunities that ICT can provide. This study uses an integrated research model (UTAUT2 + Schwartz's basic values + ICT skills) as a framework to address which factors influence ICT acceptance among individuals. Especially, to investigate to what extent basic values and ICT skills influence ICT acceptance. The study was conducted in a sub-Saharan country, contributing to the body of research on the Africa region. The findings reveal that performance expectancy, facilitating conditions, habit, hedonism, benevolence and universalism were important to form individuals' intention to adopt ICT. Whereas, to explain ICT use, ICT skills, habit, and behavioral intention were the most important facilitators, and benevolence was the most important inhibitor. The empirical results thus provide insights for both research and practice. 


\section{BIBLIOGRAPHY}

Agarwal, R., \& Karahanna, E. (2000). Time flies when you're having fun: Cognitive absorption and beliefs about information technology usage. MIS Quarterly, 24(4), 665-694.

Ajzen, I. (1991). The theory of planned behavior. Orgnizational Behavior and Human Decision Processes, 50, 179-211. http://doi.org/10.1016/0749-5978(91)90020-T

Anderson, J. C., \& Gerbing, D. W. (1988). Structural equation modeling in practice: A review and recommended two-step approach. Psychological Bulletin, 103(3), 411-423.

Andrade, A. D., \& Doolin, B. (2016). Information and communication technology and the social inclusion of refugees. MIS Quarterly, 40(2), 405-4016.

Attewell, P. (2001). The first and second digital divides. Sociology of Education, 74(3), 252-259. http://doi.org/http://www.jstor.org/stable/2673277

Bagchi, K. K., Udo, G. J., Kirs, P. J., \& Choden, K. (2015). Internet use and human values: Analyses of developing and developed countries. Computers in Human Behavior, 50, 76-90. http://doi.org/10.1016/j.chb.2015.03.055

Bandura, A. (1986). Social foundations of thought and action: A social cognitive theory. N.J: PrenticeHall, Inc.

Baptista, G., \& Oliveira, T. (2015). Understanding mobile banking: The unified theory of acceptance and use of technology combined with cultural moderators. Computers in Human Behavior, 50, 418-430. http://doi.org/10.1016/j.chb.2015.04.024

Bardi, A., \& Schwartz, S. H. (2003). Values and behavior: Strength and structure of relations. Personality and Social Psychology Bulletin, 29(10), 1207-1220. http://doi.org/10.1177/0146167203254602

Bhattacherjee, A., \& Sanford, C. (2006). Influence process for information technology acceptance: An elaboration likelihood model. MIS Quarterly, 30(4), 805-825.

Billon, M., Marco, R., \& Lera-Lopez, F. (2009). Disparities in ICT adoption: A multidimensional approach to study the cross-country digital divide. Telecommunications Policy, 33(10-11), 596610. http://doi.org/10.1016/j.telpol.2009.08.006

Bonfadelli, H. (2002). The Internet and knowledge gaps: A theoretical and empirical investigation. European Journal of Communication, 17(1), 65-84. http://doi.org/10.1177/0267323102017001607

Bornman, E. (2016). Information society and digital divide in South Africa: Results of longitudinal surveys. Information, Communication \& Society, 19(2), 264-278. http://doi.org/10.1080/1369118X.2015.1065285

Brandtzæg, P. B., Heim, J., \& Karahasanović, A. (2011). Understanding the new digital divide-A typology of Internet users in Europe. International Journal of Human-Computer Studies, 69(3), 123-138. http://doi.org/10.1016/j.ijhcs.2010.11.004

Brown, S. A., \& Venkatesh, V. (2005). Model of adoptin of technology in households: A baseline model test and extension incorporating household life cycle. MIS Quarterly, 29(3), 399-426.

Chen, D., Lin, Z., \& Lai, F. (2010). Crossing the chasm - Understanding China's rural digital divide. 
Journal of Global Information Technology Management, 13(2), 4-36. http://doi.org/10.1080/1097198X.2010.10856513

Chin, W. W. (1998). Issues and opinion on structural equation modeling. MIS Quarterly, 22(1), 7-25. http://doi.org/Editorial

Çilan, Ç., a, Bolat, B. A., \& Coşkun, E. (2009). Analyzing digital divide within and between member and candidate countries of European Union. Government Information Quarterly, 26(1), 98-105. http://doi.org/10.1016/j.giq.2007.11.002

Correa, T. (2010). The participation divide among "online experts": Experience, skills and psychological factors as predictors of college students' Web content creation. Journal of Computer-Mediated Communication, 16(1), 71-92. http://doi.org/10.1111/j.10836101.2010.01532.x

Cruz-Jesus, F., Oliveira, T., \& Bacao, F. (2012). Digital divide across the European Union. Information Management, 49(6), 278-291. http://doi.org/10.1016/j.im.2012.09.003

Cruz-Jesus, F., Vicente, M. R., Bacao, F., \& Oliveira, T. (2016). The education-related digital divide: An analysis for the EU-28. Computers in Human Behavior, 56, 72-82. http://doi.org/10.1016/j.chb.2015.11.027

Cuervo, M. R. V., \& Menéndez, A. J. L. (2006). A Multivariate framework for the analysis of the digital divide: Evidence for the European Union-15. Information \& Management, 43(6), 756-766. http://doi.org/10.1016/j.im.2006.05.001

Davidov, E., Schmidt, P., \& Schwartz, S. H. (2008). Bringing values back in: The adequacy of the European Social Survey to measure values in 20 countries. Public Opinion Quarterly, 72(3), 420445. http://doi.org/10.1093/poq/nfn035

Davis, F. D. (1989). Information technology introduction perceived usefulness and perceived ease of use. MIS Quarterly, 319-340.

Davis, F. D., Bagozzi, R. P., \& Warshaw, P. R. (1992). Extrinsic and intrinsic motivation to use computers in the workplace. Journal of Applied Social Psychology, 22(14), 1111-1132. http://doi.org/10.1111/j.1559-1816.1992.tb00945.x

Dewan, S., Ganley, D., \& Kraemer, K. L. (2010). Complementarities in the diffusion of personal computers and the internet: Implications for the global digital divide. Information Systems Research, 21(4), 925-940. http://doi.org/10.1287/isre.1080.0219

Dewan, S., \& Riggins, F. J. (2005). The digital divide: Current and future research directions. Journal of the Association for Information Systems, 6(12), 298-337.

Dimaggio, P., Hargittai, E., Celeste, C., \& Shafer, S. (2001). From unequal access to differentiated use: A literature review and agenda for research on digital inequality. Social Inequality, 355-400.

Doong, S. H., \& Ho, S.-C. (2012). The impact of ICT development on the global digital divide. Electronic Commerce Research and Applications, 11(5), 518-533. http://doi.org/10.1016/j.elerap.2012.02.002

Dragulanescu, N.-G. (2002). Social impact of the "Digital Divide" in a central-eastern European country. The International Information \& Library Review, 34(2), 139-151. http://doi.org/10.1080/10572317.2002.10762570 
Eamon, M. K. (2004). Digital divide in computer access and use between poor and non-poor youth. Journal of Sociology and Social Welfare, 31(2), 91-112.

European Commission. (2010a). A digital agenda for Europe. Brussels. http://doi.org/COM(2010)245 final

European Commission. (2010b). Europe 2020 - A strategy for smart, sustainable and inclusive growth. Brussels. http://doi.org/10.1016/j.resconrec.2010.03.010

Eurostat. (2016). Community survey on ICT usage in households and by individuals, 1-12.

Farrell, G., Isaacs, S., \& Trucano, M. (2007). The NEPAD e-Schools demonstration project: a work in progress.

Ferro, E., Helbig, N. C., \& Gil-Garcia, J. R. (2011). The role of IT literacy in defining digital divide policy needs. Government Information Quarterly, 28(1), 3-10. http://doi.org/10.1016/j.giq.2010.05.007

Fishbein, M., \& Ajzen, I. (1975). Belief, attitude, intention, and behavior: An introduction to theory and research.

Fornell, C., \& Larcker, D. F. (1981). Evaluating structural equation models with unobservable variables and measurement error. Journal of Marketing Research, 18(1), 39-50. JOUR. http://doi.org/10.2307/3151312

Ghobadi, S., \& Ghobadi, Z. (2013). How access gaps interact and shape digital divide: A cognitive investigation. Behaviour \& Information Technology, 34(4), 330-340. http://doi.org/10.1080/0144929X.2013.833650

Guerrieri, P., \& Padoan, P. C. (2007). Modelling ICT as a general purpose technology: Evaluation models and tools for assessment of innovation and sustainable development at the EU level. Collegium, 35.

Gunkel, D. J. (2003). Second thoughts: Toward a critique of the digital divide. New Media \& Society, 5(4), 499-522. http://doi.org/10.1177/146144480354003

Gupta, B., Dasgupta, S., \& Gupta, A. (2008). Adoption of ICT in a government organization in a developing country: An empirical study. The Journal of Strategic Information Systems, 17(2), 140-154. http://doi.org/10.1016/j.jsis.2007.12.004

Hair, J. F., Ringle, C. M., \& Sarstedt, M. (2011). PLS-SEM: Indeed a silver bullet. The Journal of Marketing Theory and Practice, 19(2), 139-152. http://doi.org/10.2753/MTP1069-6679190202

Hargittai, E. (2005). Survey measures of web-oriented digital literacy. Social Science Computer Review, 23(3), 371-379. http://doi.org/10.1177/0894439305275911

Hargittai, E. (2006). Hurdles to information seeking: Spelling and typographical mistakes during users' online behavior. Journal of the Association for Information Systems, 7(1), 52-67. http://doi.org/Article

Henseler, J., Ringle, C. M., \& Sarstedt, M. (2015). A new criterion for assessing discriminant validity in variance-based structural equation modeling. Journal of the Academy of Marketing Science, 43(1), 115-135. http://doi.org/10.1007/s11747-014-0403-8

Henseler, J., Ringle, C. M., \& Sinkovics, R. R. (2009). The use of partial least squares path modeling in international marketing. Advances in International Marketing, 20, 277-319. 
http://doi.org/10.1016/0167-8116(92)90003-4

Hoffman, D. L., \& Novak, T. P. (1998). Information access: Bridging the racial divide on the Internet. Science, 280(5362), 390-391. http://doi.org/10.1126/science.280.5362.390

Hofstede, G. H. (1980). Culture's consequences: International differences in work-related values. Beverly Hills, CA: Sage Publications. http://doi.org/10.5465/AME.2004.12689661

Hsieh, J. J. P.-A., Rai, A., \& Keil, M. (2008). Understanding digital inequality: Comparing continued use behavioral models of the socio-economically advantaged and disadvantaged. MIS Quarterly, 32(1), 97-126.

ITU. (2014a). Manual for measuring ICT access and use by households and individuals.

ITU. (2014b). Measuring the information society report. http://doi.org/10.3359/oz0303157

ITU. (2015). Measuring the information society: The ICT development index. International Telecommunication Union. http://doi.org/10.3359/oz0303157

Karahanna, E., Straub, W. D., \& Chervanny, L. N. (1999). Information technology adoption across time: A cross-sectional comparison of pre-adoption and post-adoption beliefs. MIS Quarterly, 23(2), 183-213.

Kurfalı, M., Arifoğlu, A., Tokdemir, G., \& Paçin, Y. (2017). Adoption of e-government services in Turkey. Computers in Human Behavior, 66, 168-178. http://doi.org/10.1016/j.chb.2016.09.041

Lee, H., Park, N., \& Hwang, Y. (2015). A new dimension of the digital divide: Exploring the relationship between broadband connection, smartphone use and communication competence. Telematics and Informatics, 32(1), 45-56. http://doi.org/10.1016/j.tele.2014.02.001

Liao, C., Chen, J. L., \& Yen, D. C. (2007). Theory of planning behavior (TPB) and customer satisfaction in the continued use of e-service: An integrated model. Computers in Human Behavior, 23(6), 2804-2822. http://doi.org/10.1016/j.chb.2006.05.006

Limayem, M., Hirt, S. G., \& Cheung, C. M. K. (2007). How habit limits the predictive power of intention: The case of information systems continuance. MIS Quarterly, 31(4), 705-737.

Lindell, M. K., \& Whitney, D. J. (2001). Accounting for common method variance in cross-sectional research designs. Journal of Applied Psychology, 86(1), 114-121. http://doi.org/10.1037/00219010.86.1.114

Magsamen-Conrad, K., Upadhyaya, S., Joa, C. Y., \& Dowd, J. (2015). Bridging the divide: Using UTAUT to predict multigenerational tablet adoption practices. Computers in Human Behavior, 50, 186196. http://doi.org/10.1016/j.chb.2015.03.032

Malhotra, N. K., Kim, S. S., \& Patil, A. (2006). Common method variance in IS research: A comparison of alternative approaches and a reanalysis of past research. Management Science, 52(12), 1865-1883. http://doi.org/10.1287/mnsc.1060.0597

Martins, C., Oliveira, T., \& Popovic, A. (2014). Understanding the internet banking adoption by portuguese customers: A unified theory of acceptance and use of technology and perceived risk application. International Journal of Information Management, 34, 1-13.

Niehaves, B., \& Plattfaut, R. (2014). Internet adoption by the elderly: Employing IS technology acceptance theories for understanding the age-related digital divide. European Journal of Information System, 23(6), 708-726. http://doi.org/10.1057/ejis.2013.19 
NTIA. (1995). Falling through the net: A survey of the "Have Nots" in rural and urban America. Retrieved from http://www.ntia.doc.gov/ntiahome/fallingthru.html

NTIA. (1998). Falling through the net II: New data on the digital divide. Retrieved from http://www.ntia.doc.gov/ntiahome/net2

NTIA. (1999). Falling through the net: Defining the digital divide. Retrieved from http://www.ntia.doc.gov/legacy/ntiahome/fttn99/contents.html

NTIA. (2000). Falling through the net II: Toward digital inclusion. Retrieved from http://www.ntia.doc.gov/ntiahome/fttn00/contents00.html

OECD. (2001). Understanding the digital divide, (1), 52-54. http://doi.org/10.1093/ilj/6.1.52

OECD. (2004). The economic impact of ICT. http://doi.org/10.1787/9789264026780-en

OECD. (2011). OECD Guide to measuring the information society 2011. http://doi.org/10.1787/9789264113541-en

Partala, T., \& Saari, T. (2015). Understanding the most influential user experiences in successful and unsuccessful technology adoptions. Computers in Human Behavior, 53, 381-395. http://doi.org/10.1016/j.chb.2015.07.012

Pavlou, P. A., \& Fygenson, M. (2006). Understanding and predicting electronic commerce adoption: An extension of the theory of planned behavior. MIS Quarterly, 30(1), 115-143.

Payton, F. C. (2003). Rethinking the digital divide when industry analyst forrester. Communications of the ACM, 46(6), 89-91.

Podsakoff, P. M., MacKenzie, S. B., Lee, J.-Y., \& Podsakoff, N. P. (2003). Common method biases in behavioral research: a critical review of the literature and recommended remedies. The Journal of Applied Psychology, 88(5), 879-903. http://doi.org/10.1037/0021-9010.88.5.879

Qingfei, M., Shaobo, J., \& Gang, Q. (2008). Mobile commerce user acceptance study in China: A revised UTAUT model. Tsinghua Science and Technology, 13(3), 257-264. http://doi.org/10.1016/S1007-0214(08)70042-7

Ringle, Christian M., Wende, Sven, \& Becker, J.-M. (2015). SmartPLS 3. Bönningstedt: SmartPLS. Retrieved from http://www.smartpls.com

Rogers, E. M. (1995). Diffusion of innovations. New York, NY: The Free Press.

Schlichter, B. R., \& Danylchenko, L. (2014). Measuring ICT usage quality for information society building. Government Information Quarterly, 31(1), 170-184. http://doi.org/10.1016/j.giq.2013.09.003

Schradie, J. (2011). The digital production gap: The digital divide and Web 2.0 collide. Poetics, 39(2), 145-168. http://doi.org/10.1016/j.poetic.2011.02.003

Schwartz, S. H. (1992). Universals in the content and structure of values: Theoretical advances and empirical tests in 20 countries. Advances in Experimental Social Psychology, 25(C), 1-65. http://doi.org/10.1016/S0065-2601(08)60281-6

Schwartz, S. H. (2012). An overview of the Schwartz theory of basic values an overview of the Schwartz theory of basic values. Online Readings in Psycology and Culture, 2(1). http://doi.org/10.9707/2307-0919.1116 
Schwartz, S. H., Cieciuch, J., Vecchione, M., Davidov, E., Fischer, R., Beierlein, C., ... Konty, M. (2012). Refining the theory of basic individual values. Journal of Personality and Social Psychology, 103(4), 663-688. http://doi.org/10.1037/a0029393

Selwyn, N. (2006). Digital division or digital decision? A study of non-users and low-users of computers. Poetics, 34(4-5), 273-292. http://doi.org/10.1016/j.poetic.2006.05.003

Selwyn, N., \& Facer, K. (2007). Beyond the digital divide: Rethinking digital inclusion for the 21st century. Retrieved from http://www.nfer.ac.uk/publications/FUTL55

Setterstrom, A. J., Pearson, J. M., \& Orwig, R. a. (2013). Web-enabled wireless technology: An exploratory study of adoption and continued use intentions. Behaviour \& Information Technology, 32(11), 1139-1154. http://doi.org/10.1080/0144929X.2012.708785

Smith, P. B. (2002). Levels of analysis in cross-cultural psychology. Online Readings in Psycology and Culture, 2(2). http://doi.org/10.9707/2307-0919.1018

Srite, M., \& Karahanna, E. (2006). The role of espoused national cultural values in technology acceptance. MIS Quarterly, 30(3), 679-704. http://doi.org/10.1093/ajae/aau104

Taylor, S., \& Todd, P. A. (1995). Understanding information technology usage: A test of competing models. Information Systems Research, 6(2), 144-176.

Thompson, R. L., Higgins, C. A., \& Howell, J. . (1991). Personal computing : toward a conceptual model of utilization. MIS Quarterly, 15(1), 124-143.

Udo, G. J., Bagchi, K. K., \& Kirs, P. J. (2012). Exploring the role of espoused values on e-service adoption: A comparative analysis of the US and Nigerian users. Computers in Human Behavior, 28(5), 1768-1781. http://doi.org/10.1016/j.chb.2012.04.017

UNCTAD. (2011). Measuring the impacts of information and communication technology for development. New York and Geneva. Retrieved from http://unctad.org/en/docs/dtlstict2011d1_en.pdf

UNDP. (2015). Human Development Report 2015. New York. Retrieved from http://hdr.undp.org/sites/default/files/2015_human_development_report_1.pdf

US Department of Commerce. (2002). A nation online: How Americans are expanding their use of the Internet.

van der Heijden, H. (2004). User acceptance of hedonic information systems. MIS Quarterly, 27(3), 425-478.

van Deursen, A. J. A. ., van Dijk, J. A. G. ., \& Ten Klooster, P. M. (2015). Increasing inequalities in what we do online: A longitudinal cross sectional analysis of Internet activities among the Dutch population (2010 to 2013) over gender, age, education, and income. Telematics and Informatics, 32(2), 259-272. http://doi.org/10.1016/j.tele.2014.09.003

van Deursen, A. J. A. M., Helsper, E. J., \& Eynon, R. (2016). Development and validation of the Internet skills scale (ISS). Information, Communication \& Society, 19(6), 804-823. http://doi.org/10.1080/1369118X.2015.1078834

van Deursen, A. J. A. M., \& van Dijk, J. A. G. M. (2015). Internet skill levels increase, but gaps widen: A longitudinal cross-sectional analysis (2010-2013) among the Dutch population. Information, Communication \& Society, 18(7), 782-797. http://doi.org/10.1080/1369118X.2014.994544 
van Dijk, J. A. G. M. (2006). Digital divide research, achievements and shortcomings. Poetics, 34(4-5), 221-235. http://doi.org/10.1016/j.poetic.2006.05.004

Várallyai, L., Herdon, M., \& Botos, S. (2015). Statistical analyses of digital divide factors. Procedia Economics and Finance, 19(15), 364-372. http://doi.org/10.1016/S2212-5671(15)00037-4

Venkatesh, V., \& Brown, S. A. (2001). A longitudinal investigation of personal computers in homes: Adoption determinants and emerging challenges. MIS Quarterly, 25(1), 71-102.

Venkatesh, V., Brown, S. A., Maruping, L. M., \& Bala, H. (2008). Predicting different conceptualizations of system use: The competing roles of behavioral intention, facilitating conditions, and behavioral expectation. MIS Quarterly, 32(3), 483-502.

Venkatesh, V., Morris, M. G., Davis, G. B., \& Davis, F. D. (2003). User acceptance of information technology: Toward a unified view. MIS Quarterly, 27(3), 425-478. http://doi.org/10.2307/30036540

Venkatesh, V., \& Sykes, T. A. (2013). Digital divide initiative success in developing countries: A longitudinal field study in a village in India. Information Systems Research, 24(2), 239-270. http://doi.org/10.1287/isre.1110.0409

Venkatesh, V., Thong, J. Y. L., \& Xu, X. (2012). Consumer acceptance and use of information technology: Extending the unified theory. MIS Quarterly, 36(1), 157-178.

Venkatesh, V., Thong, J. Y. L., \& Xu, X. (2016). Unified theory of acceptance and use of technology: A synthesis and the road ahead. Journal of the Association for Information Systems, 17(5), 328376.

Weber, D. M., \& Kauffman, R. J. (2011). What drives global ICT adoption? Analysis and research directions. Electronic Commerce Research and Applications, 10(6), 683-701. http://doi.org/10.1016/j.elerap.2011.01.001

WSIS. (2005). Declaration of principles: Building the information society: A global challenge in the new millennium. Tunis. http://doi.org/10.1177/0016549204043613

Wu, J. H., \& Wang, S. C. (2005). What drives mobile commerce? An empirical evaluation of the revised technology acceptance model. Information and Management, 42(5), 719-729. http://doi.org/10.1016/j.im.2004.07.001

Zhang, X. (2017). Exploring the patterns and determinants of the global mobile divide. Telematics and Informatics, 34, 438-449. http://doi.org/10.1016/j.tele.2016.06.010

Zhang, X., \& Maruping, L. M. (2008). Household technology adoption in a global marketplace: Incorporating the role of espoused cultural values. Information Systems Frontiers, 10(4), 403413. http://doi.org/10.1007/s10796-008-9099-y

Zhou, T., Lu, Y., \& Wang, B. (2010). Integrating TTF and UTAUT to explain mobile banking user adoption. Computers in Human Behavior, 26(4), 760-767. http://doi.org/10.1016/j.chb.2010.01.013 


\section{APPENDIX A - PRIOR RESEARCH ON DIGITAL DIVIDE}

\begin{tabular}{|c|c|c|c|}
\hline ICT under study & Variables & Findings & Authors \\
\hline $\begin{array}{l}\text { PC and modem } \\
\text { penetration across US }\end{array}$ & $\begin{array}{l}\text { Computer, telephone and modem penetration, } \\
\text { income, age, education, race, geographic region }\end{array}$ & $\begin{array}{l}\text { PC and modem penetration is lower in } \\
\text { rural areas among less educated, lower } \\
\text { income and belonging to minority } \\
\text { ethnicities }\end{array}$ & (NTIA, 1995) \\
\hline $\begin{array}{l}\text { PC and modem } \\
\text { penetration across US }\end{array}$ & $\begin{array}{l}\text { Telephone, Computer and Modem penetration, } \\
\text { income, age, education, race, geographic region, } \\
\text { household type }\end{array}$ & $\begin{array}{l}\text { Education influence more than income } \\
\text { concerning higher penetration levels. } \\
\text { Households composed by married couples } \\
\text { with children have higher levels of both } \\
\text { telephone and PC/modem penetration }\end{array}$ & (NTIA, 1998) \\
\hline $\begin{array}{l}\text { Internet access and } \\
\text { usage across US }\end{array}$ & $\begin{array}{l}\text { PC, Internet use, income, age, education, race, } \\
\text { household type, geographic region, employment }\end{array}$ & $\begin{array}{l}\text { Education and income are the main } \\
\text { predictors of Internet access and use. } \\
\text { Internet is used for educational purposes } \\
\text { and as a communication tool }\end{array}$ & $\begin{array}{c}\text { NTIA } \\
(1999,2000)\end{array}$ \\
\hline $\begin{array}{l}\text { Internet access and } \\
\text { use }\end{array}$ & $\begin{array}{l}\text { Internet use, age, gender, income, education, } \\
\text { frequency of Internet use, Internet content use, } \\
\text { self-rated computer skills, attitudes toward } \\
\text { Internet }\end{array}$ & $\begin{array}{l}\text { People with lower education use the } \\
\text { Internet mostly for entertainment } \\
\text { reasons. Besides education, gender and } \\
\text { age also discriminate between Internet } \\
\text { users }\end{array}$ & $\begin{array}{l}\text { Bonfandelli } \\
\text { (2002) }\end{array}$ \\
\hline $\begin{array}{l}\text { Computer and } \\
\text { Internet access } \\
\text { among African- } \\
\text { American teenagers }\end{array}$ & $\begin{array}{l}\text { Computer access, intended college major, online } \\
\text { activities }\end{array}$ & $\begin{array}{l}\text { There is a less tangible divide in form of } \\
\text { limited access to social networks }\end{array}$ & Payton (2003) \\
\hline $\begin{array}{l}\text { Home computer } \\
\text { ownership and use }\end{array}$ & $\begin{array}{l}\text { Home computer ownership, academic home } \\
\text { computer use, poverty, age, gender, } \\
\text { race/ethnicity, mother's marital status, mother's } \\
\text { years of education }\end{array}$ & $\begin{array}{l}\text { Poverty is a major factor for predicting } \\
\text { ownership, but there is no significant } \\
\text { relation with usage }\end{array}$ & (Eamon, 2004) \\
\hline $\begin{array}{l}\text { Online information- } \\
\text { seeking behavior }\end{array}$ & $\begin{array}{l}\text { Online searching abilities, age, education, } \\
\text { income, use years, Web time, freedom to use Net } \\
\text { at work }\end{array}$ & $\begin{array}{l}\text { Existing social inequalities translate into } \\
\text { different online behavior }\end{array}$ & $\begin{array}{l}\text { Hargittai } \\
(2006)\end{array}$ \\
\hline $\begin{array}{l}\text { Internet TV between } \\
\text { socio-economically } \\
\text { advantaged and } \\
\text { disadvantaged }\end{array}$ & $\begin{array}{l}\text { Internet TV continued use intention, attitude, } \\
\text { hedonic outcomes, utilitarian outcomes, } \\
\text { subjective norms, family relatives friends and } \\
\text { peers' influence, governmental influence, } \\
\text { perceived behavioral control, self-efficacy, } \\
\text { perceived ease of use, availability, personal } \\
\text { network exposure, Internet PC ownership }\end{array}$ & $\begin{array}{l}\text { Attitude has a great influence on intention } \\
\text { to use technology. Social network affects } \\
\text { acceptance and has a strong influence in } \\
\text { socio-economically advantaged }\end{array}$ & $\begin{array}{l}\text { (Hsieh et al., } \\
\text { 2008) }\end{array}$ \\
\hline $\begin{array}{l}\text { Individuals' IT skills } \\
\text { acquisition }\end{array}$ & $\begin{array}{l}\text { Internet access and use, income, age, education, } \\
\text { attitude towards computers, nationality, location, } \\
\text { gender, other language, pc at home, PC use, IT } \\
\text { skills, household size, occupation }\end{array}$ & $\begin{array}{l}\text { IT literacy is positively associated with } \\
\text { Internet access, however is not sufficient } \\
\text { condition alone for Internet access and } \\
\text { use }\end{array}$ & $\begin{array}{l}\text { (Ferro et al., } \\
\text { 2011) }\end{array}$ \\
\hline $\begin{array}{l}\text { Internet adoption by } \\
\text { the elderly }\end{array}$ & $\begin{array}{l}\text { Internet adoption behavioral intention, } \\
\text { performance expectancy, effort expectancy, } \\
\text { social influence, facilitating conditions, } \\
\text { applications for personal use, utility for children, } \\
\text { applications for fun, status gains, friends and } \\
\text { family influence, secondary sources influences, } \\
\text { fear of technological advances, declining cost, } \\
\text { cost, perceived ease of use, self-efficacy, age, } \\
\text { gender, education, income }\end{array}$ & $\begin{array}{l}\text { Both UTAUT and MATH are able to explain } \\
\text { Internet adoption by the elderly. } \\
\text { Education has a positive effect on Internet } \\
\text { adoption while age has a negative effect }\end{array}$ & $\begin{array}{l}\text { (Niehaves \& } \\
\text { Plattfaut, } \\
\text { 2014) }\end{array}$ \\
\hline Internet skills & $\begin{array}{l}\text { Operational skills, formal skills, information skills, } \\
\text { strategic skills, age, gender, education, }\end{array}$ & $\begin{array}{l}\text { Education shows a positive effect on all } \\
\text { four Internet skills. Information skills } \\
\text { require a base of knowledge and } \\
\text { understanding accumulated through } \\
\text { lifelong learning }\end{array}$ & $\begin{array}{l}\text { (van Deursen } \\
\text { \& van Dijk, } \\
\text { 2015) }\end{array}$ \\
\hline
\end{tabular}




\section{APPENDIX B - ITEMS LIST}

\begin{tabular}{|c|c|c|c|}
\hline Constructs & Code & Items & Source \\
\hline \multirow{4}{*}{$\begin{array}{l}\text { Performance } \\
\text { Expectancy (PE) }\end{array}$} & PE1 & I find ICT useful in my daily life. & \multirow{4}{*}{$\begin{array}{l}\text { (Venkatesh et } \\
\text { al., 2012) }\end{array}$} \\
\hline & PE2 & $\begin{array}{l}\text { Using ICT increases my chances of achieving things that are important to } \\
\text { me. }\end{array}$ & \\
\hline & PE3 & Using ICT helps me accomplish things more quickly. & \\
\hline & PE4 & Using ICT increase my productivity. & \\
\hline \multirow{4}{*}{$\begin{array}{l}\text { Effort Expectancy } \\
\qquad(\mathrm{EE})\end{array}$} & EE1 & Learning how to use ICT is easy for me. & \multirow{4}{*}{$\begin{array}{l}\text { (Venkatesh et } \\
\text { al., 2012) }\end{array}$} \\
\hline & EE2 & My interaction with ICT is clear and understandable. & \\
\hline & EE3 & I find ICT easy to use. & \\
\hline & EE4 & It is easy for me to become skillful at using ICT. & \\
\hline \multirow{3}{*}{$\begin{array}{l}\text { Social Influence } \\
\qquad(\mathrm{SI})\end{array}$} & SI1 & People who are important to me think that I should use ICT. & \multirow{3}{*}{$\begin{array}{l}\text { (Venkatesh et } \\
\text { al., 2012) }\end{array}$} \\
\hline & $\mathrm{SI} 2$ & People who influence my behavior think that I should use ICT. & \\
\hline & SI3 & People whose opinions that I value prefer that I use ICT. & \\
\hline \multirow{4}{*}{$\begin{array}{c}\text { Facilitating } \\
\text { Conditions (FC) }\end{array}$} & FC1 & I have the resources necessary to use ICT. & \multirow{4}{*}{$\begin{array}{l}\text { (Venkatesh et } \\
\text { al., 2012) }\end{array}$} \\
\hline & FC2 & I have the knowledge necessary to use ICT. & \\
\hline & FC3 & ICT is compatible with other technologies I use. & \\
\hline & FC4 & I can get help from others when I have difficulties using ICT. & \\
\hline \multirow{3}{*}{$\begin{array}{l}\text { Hedonic } \\
\text { Motivation (HM) }\end{array}$} & HM1 & Using ICT is fun. & \multirow{3}{*}{$\begin{array}{l}\text { (Venkatesh et } \\
\text { al., 2012) }\end{array}$} \\
\hline & HM2 & Using ICT is enjoyable. & \\
\hline & HM3 & Using ICT is very entertaining. & \\
\hline \multirow[t]{3}{*}{ Price Value (PV) } & PV1 & ICT is reasonably priced. & \multirow{3}{*}{$\begin{array}{l}\text { (Venkatesh et } \\
\text { al., 2012) }\end{array}$} \\
\hline & PV2 & ICT is a good value for the money. & \\
\hline & PV3 & At the current price, ICT provides a good value. & \\
\hline \multirow[t]{4}{*}{ Habit (HB) } & HB1 & The use of ICT has become a habit for me. & \multirow{4}{*}{$\begin{array}{l}\text { (Venkatesh et } \\
\text { al., 2012) }\end{array}$} \\
\hline & HB2 & I am addicted to using ICT. & \\
\hline & HB3 & I must use ICT. & \\
\hline & HB4 & Using ICT has become natural to me. & \\
\hline \multirow{3}{*}{$\begin{array}{l}\text { Behavioral } \\
\text { Intention (BI) }\end{array}$} & BI1 & I intend to continue using ICT in the future. & \multirow{3}{*}{$\begin{array}{l}\text { (Venkatesh et } \\
\text { al., 2012) }\end{array}$} \\
\hline & $\mathrm{BI} 2$ & I will always try to use ICT in my daily life. & \\
\hline & $\mathrm{BI} 3$ & I plan to continue to use ICT frequently. & \\
\hline \multirow[t]{4}{*}{ Use Behavior (UB) } & UB1 & On average, how many hours do you use ICT each week? & \multirow{4}{*}{$\begin{array}{l}\text { (Venkatesh et } \\
\text { al., 2008) }\end{array}$} \\
\hline & UB2 & How often do you use ICT? (i) Never; to (vii) several times each day. & \\
\hline & UB3 & $\begin{array}{l}\text { How do you consider the extent of your current ICT use? (i) Non use; to } \\
\text { (vii) heavy use. }\end{array}$ & \\
\hline & UB4 & $\begin{array}{l}\text { On average, I spend a significant amount of hours using ICT each week (i) } \\
\text { strongly disagree; to (vii) strongly agree }\end{array}$ & \\
\hline \multirow{3}{*}{$\begin{array}{l}\text { Self-direction } \\
\qquad \text { (SDT) }\end{array}$} & SDT1 & Being creative is important to him/her. & \multirow{3}{*}{$\begin{array}{l}\text { (Schwartz et al., } \\
\text { 2012) }\end{array}$} \\
\hline & SDT2 & $\begin{array}{l}\text { It is important to him/her to form his/her own opinions and have original } \\
\text { ideas. }\end{array}$ & \\
\hline & SDT3 & $\begin{array}{l}\text { Learning things for himself/herself and improving his/her abilities is } \\
\text { important to him/her. }\end{array}$ & \\
\hline \multirow[t]{3}{*}{ Stimulation (ST) } & ST1 & He/she is always looking for different kinds of things to do. & \multirow{3}{*}{$\begin{array}{l}\text { (Schwartz et al., } \\
\text { 2012) }\end{array}$} \\
\hline & ST2 & Excitement in life is important to him/her. & \\
\hline & ST3 & $\mathrm{He} /$ she thinks it is important to have all sorts of new experiences. & \\
\hline \multirow[t]{3}{*}{ Hedonism (HE) } & HE1 & Having a good time is important to him/her. & \multirow{3}{*}{$\begin{array}{l}\text { (Schwartz et al., } \\
\text { 2012) }\end{array}$} \\
\hline & HE2 & Enjoying life's pleasures is important to him/her. & \\
\hline & HE3 & He/she takes advantage of every opportunity to have fun. & \\
\hline
\end{tabular}




\begin{tabular}{|c|c|c|c|}
\hline Constructs & Code & Items & Source \\
\hline \multirow[t]{3}{*}{ Achievement (AC) } & AC1 & He/she thinks it is important to be ambitious. & \multirow{3}{*}{$\begin{array}{l}\text { (Schwartz et al., } \\
\text { 2012) }\end{array}$} \\
\hline & AC2 & Being very successful is important to him/her. & \\
\hline & AC3 & He/she wants people to admire his/her achievements. & \\
\hline \multirow{3}{*}{$\begin{array}{l}\text { Security-personal } \\
\qquad \text { (SEP) }\end{array}$} & SEP1 & He/she avoids anything that might endanger his/her safety. & \multirow{3}{*}{$\begin{array}{l}\text { (Schwartz et al., } \\
\text { 2012) }\end{array}$} \\
\hline & SEP2 & His/her personal security is extremely important to him/her. & \\
\hline & SEP3 & It is important to him/her to live in secure surroundings. & \\
\hline \multirow{3}{*}{$\begin{array}{l}\text { Security-societal } \\
\text { (SES) }\end{array}$} & SES1 & It is important to him/her that his country protect itself against all threats. & \multirow{3}{*}{$\begin{array}{l}\text { (Schwartz et al., } \\
\text { 2012) }\end{array}$} \\
\hline & SES2 & He/she wants the state to be strong so it can defend its citizens. & \\
\hline & SES3 & Having order and stability in society is important to him/her. & \\
\hline \multirow[t]{3}{*}{ Benevolence (BE) } & BE1 & It's very important to him/her to help the people dear to him/her. & \multirow{3}{*}{$\begin{array}{l}\text { (Schwartz et al., } \\
\text { 2012) }\end{array}$} \\
\hline & BE2 & $\begin{array}{l}\text { Caring for the well-being of people he/she is close to is important to } \\
\text { him/her. }\end{array}$ & \\
\hline & BE3 & $\begin{array}{l}\text { He/she tries always to be responsive to the needs of his/her family and } \\
\text { friends. }\end{array}$ & \\
\hline \multirow[t]{3}{*}{ Universalism (UN) } & UN1 & $\begin{array}{l}\text { Protecting society's weak and vulnerable members is important to } \\
\text { him/her. }\end{array}$ & \multirow[t]{3}{*}{$\begin{array}{l}\text { (Schwartz et al., } \\
\text { 2012) }\end{array}$} \\
\hline & UN2 & $\begin{array}{l}\text { He/she thinks it is important that every person in the world have equal } \\
\text { opportunities in life. }\end{array}$ & \\
\hline & UN3 & $\begin{array}{l}\text { He/she wants everyone to be treated justly, even people he/she doesn't } \\
\text { know. }\end{array}$ & \\
\hline \multirow[t]{8}{*}{ ICT Skills } & ICTS & $\begin{array}{l}\text { Which of the following software related activities have you carried out in } \\
\text { the last } 12 \text { months? }\end{array}$ & \multirow[t]{8}{*}{$\begin{array}{l}\text { (Eurostat, } \\
2016 \text { ) }\end{array}$} \\
\hline & ICTS1 & a) Copying or moving files or folders & \\
\hline & ICTS2 & b) Using word processing software & \\
\hline & ICTS3 & $\begin{array}{l}\text { c) Creating presentations or documents integrating text, pictures, tables } \\
\text { or charts }\end{array}$ & \\
\hline & ICTS4 & d) Using spreadsheet software & \\
\hline & ICTS5 & $\begin{array}{l}\text { e) Using advanced functions of spreadsheet software to organize and } \\
\text { analyze data, such as sorting, filtering, using formulas, creating charts }\end{array}$ & \\
\hline & ICTS6 & f) Using software to edit photos, video or audio files & \\
\hline & ICTS7 & g) Writing code in a programming language & \\
\hline
\end{tabular}




\section{APPENDIX C - HETEROTRAIT-MONOTRAIT RATIO (HTMT)}

\begin{tabular}{|c|c|c|c|c|c|c|c|c|c|c|c|c|c|c|c|c|c|}
\hline & PE & $\mathrm{EE}$ & SI & FC & HM & PV & HB & BI & UB & ICTS & SDT & ST & HE & AC & SE & BE & UN \\
\hline \multicolumn{18}{|l|}{$\mathrm{PE}$} \\
\hline $\mathrm{EE}$ & 0,384 & & & & & & & & & & & & & & & & \\
\hline SI & 0,578 & 0,460 & & & & & & & & & & & & & & & \\
\hline $\mathrm{FC}$ & 0,362 & 0,874 & 0,302 & & & & & & & & & & & & & & \\
\hline $\mathrm{HM}$ & 0,539 & 0,399 & 0,443 & 0,503 & & & & & & & & & & & & & \\
\hline PV & 0,275 & 0,291 & 0,217 & 0,319 & 0,140 & & & & & & & & & & & & \\
\hline $\mathrm{HB}$ & 0,615 & 0,522 & 0,538 & 0,567 & 0,560 & 0,384 & & & & & & & & & & & \\
\hline $\mathrm{BI}$ & 0,568 & 0,317 & 0,324 & 0,589 & 0,587 & 0,183 & 0,625 & & & & & & & & & & \\
\hline UB & 0,284 & 0,326 & 0,133 & 0,497 & 0,235 & 0,286 & 0,489 & 0,429 & & & & & & & & & \\
\hline ICTS & 0,161 & 0,178 & 0,032 & 0,262 & 0,139 & 0,075 & 0,244 & 0,188 & 0,358 & & & & & & & & \\
\hline SDT & 0,452 & 0,318 & 0,395 & 0,598 & 0,540 & 0,167 & 0,565 & 0,551 & 0,286 & 0,135 & & & & & & & \\
\hline ST & 0,334 & 0,581 & 0,420 & 0,812 & 0,569 & 0,271 & 0,616 & 0,579 & 0,340 & 0,078 & 0,815 & & & & & & \\
\hline $\mathrm{HE}$ & 0,313 & 0,136 & 0,261 & 0,309 & 0,519 & 0,145 & 0,286 & 0,503 & 0,197 & 0,033 & 0,570 & 0,543 & & & & & \\
\hline$A C$ & 0,251 & 0,313 & 0,352 & 0,466 & 0,371 & 0,274 & 0,337 & 0,374 & 0,408 & 0,127 & 0,542 & 0,538 & 0,625 & & & & \\
\hline SE & 0,208 & 0,128 & 0,174 & 0,375 & 0,390 & 0,153 & 0,300 & 0,433 & 0,176 & 0,223 & 0,570 & 0,337 & 0,364 & 0,413 & & & \\
\hline $\mathrm{BE}$ & 0,383 & 0,190 & 0,320 & 0,437 & 0,563 & 0,115 & 0,394 & 0,665 & 0,126 & 0,091 & 0,752 & 0,618 & 0,373 & 0,207 & 0,549 & & \\
\hline UN & 0,288 & 0,226 & 0,245 & 0,370 & 0,336 & 0,081 & 0,260 & 0,596 & 0,117 & 0,178 & 0,544 & 0,428 & 0,272 & 0,156 & 0,578 & 0,632 & \\
\hline
\end{tabular}

